\title{
Alkali Bazalt ve Piroklastik Çökellerin Volkanolojik Özellikleri, Kula Volkanları, Batı Anadolu
}

\author{
Volcanological Characteristics of Alkaline Basalt and Pyroclastic \\ Deposits, Kula Volcanoes, Western Anatolia
}

\author{
ERDAL ŞEN ${ }^{1 *}$, ERKAN AYDAR ${ }^{2}$, HASAN BAYHAN ${ }^{1}$, ALAIN GOURGAUD ${ }^{3}$ \\ ${ }^{1}$ Hacettepe Üniversitesi, Jeoloji Mühendisliği Bölümü, Beytepe, 06800, Ankara \\ ${ }^{2}$ ATERRA R\&D, Yüksel Cad. 30/8, Kızılay, Ankara \\ ${ }^{3}$ Blaise Pascal University, UMR - CNRS 6524, 5 rue Kessler, 63038, Clermont-Ferrand Cedex, France \\ Geliș (received) : 10 Ekim (October) 2014 \\ Kabul (accepted) : 10 Aralık (December) 2014
}

Öz

Kula Volkanik Alanı (KVA) Türkiye'nin Batı Anadolu bölgesindeki Gediz Grabeni ile Simav Grabeni arasında bulunan Selendi baseninde yer almaktadır. Kula volkanizmasının gelișim süreci üç evreye ayrılmıștır: Illk evre (B-I, 1,94 $\pm 0,16-0,99 \pm 0,11$ milyon yıl) zayıf patlamaların ürettiği, kalınlığı $40-50 \mathrm{~cm}$ olan cüruf kül geri-düșme ürünleri ile bașlamıș ve sonrasında iyi gelișmiș sütun yapıları içeren plato bazaltlar ile devam etmiștir. Monojenetik volkanların olușumu Kula volkanizmasının en yüksek hacimli lavlarına eșlik eden ikinci evre ile bașlamıștır (B-II, $300 \pm 3-50 \pm$ 9 bin yıl). KVA'nın son evre ürünleri ise, (B-III, $25 \pm 7-4 \pm 2$ bin yıl) yüzeyi oldukça pürüzlü, gözenekli, keskin kenar bloklu ve kırık, ancak iç kısmı yoğun ve sütun soğuma yapıları içeren 'a'a tip bazaltik lav akıntıları ile karakterize edilmektedir. KVA 80 cüruf konisi, 5 maar, 8 sıçratma konisi ve 6 tümülüs içermektedir. KVA'nın volkanik ürünleri bazanit ve fonotefrit olarak sınıflandırımaktadır. Tüm ürünler alkali karakterdedir. Bazaltik lavlar baskın olarak klinopiroksen, olivin, hornblend (B-II ve B-III evreleri için), plajiyoklaz ve feldispatoid fenokristallerinden olușmaktadır. Sahada detaylı morfolojik araștırmaların yanı sıra topografik haritalar da kullanılarak piroklastik çökellerin hacimleri hesaplanmıștır. Cüruf konileri, 556 m. medyan taban çapına (Wco), 45 m medyan yüksekliğine (Hco) ve 5,4 x 106 $\mathrm{m}^{3}$ medyan hacmine $\left(V_{c}\right)$ sahiptir. Püsküren toplam malzemenin hacmi $\left(V_{T}\right) 3,25 \mathrm{~km}^{3}$ Yoğun Kayaç Eșitliğidir (YKE). Koniler 3-39 arası koni taban çapı / koni yükseklik oranına (Wco/Hco) ve $2,3^{\circ}$ ve $45^{\circ}$ arasında değișen yamaç eğimine $(\theta)$ sahiptir. Maarlar ise 8-40 arası ortalama çap / derinlik oranına (Do/d) sahiptir. Püsküren toplam malzeme hacmi $\left(V_{E}\right)$ 0,36 km $\mathrm{kKE}^{3}$ ve toplam jüvenil bileșen hacmi $\left(V_{\jmath}\right)$ 0,34 km³ YKE olarak hesaplanmıștır. Volkanik merkezlerden çıkan alkali bazaltik lavların hacmi ise en az $2,3 \mathrm{~km}^{3}$ olup, tüm ürünlerin toplam hacmi $\sim 5,9 \mathrm{~km}^{3}$ civarındadır. B-II ve B-III cüruf konileri arasındaki morfolojik değișim așınma oranına bağlıdır.

Anahtar Kelimeler: Alkali bazalt, cüruf konisi, maar, lavlar, piroklastik ürünler, hacimsel hesaplamalar, Kula Volkanik Alanı

\begin{abstract}
Kula Volcanic Field (KVF) is situated in Selendi Basin between Gediz and Simav Grabens in Western Anatolia. The evolutionary stages of Kula volcanism have been identified as: First stage (B-I, 1,94 0,16 - 0,99 \pm 0,11 ma) commences with weak pyroclastic explosions producing scoria ash fall deposits with an average thickness of 40-50 cm, and followed by lava flows forming plateau basalts with well-developed columnar joints. Monogenetic volcanism begins with the second stage ( $B-I I, 300 \pm 3-50 \pm 9 \mathrm{ka}$ ) and accompanied with the most voluminous lavas of Kula volcanism. The last stage products of the KVF (B-III, $25 \pm 7-4 \pm 2 \mathrm{ka}$ ) are 'a'a type basaltic lava flows and characterized by rough and sharp edged blocks, vesiculated and broken surfaces, but with dense interior of columnar
\end{abstract}

\footnotetext{
*E. Șen

e-posta: erdals@hacettepe.edu.tr
} 
joint structures. The KVF consists of 80 cinder cones, 5 maars, 8 spatter cones and 6 tumuli. The volcanic products of KVF are alkaline in character and classified as basanite and phonotephrite according to chemical compositions. The dominant mineralogical assemblage in basaltic lavas is comprised of clinopyroxene, olivine, hornblende (for $B$-II and B-III stage), plagioclase and feldspathoids. The volume of the pyroclastic deposits is estimated by detailed morphological investigations in the field as well as by using the topographic maps. Cinder cones have a median basal diameter (Wco) of $556 \mathrm{~m}$, a median height ( $\mathrm{Hco}$ ) of $45 \mathrm{~m}$, and a median volume $\left(\mathrm{V}_{\mathrm{d}}\right.$ ) of $5.4^{*} 106 \mathrm{~m}^{3}$. The total erupted volume $\left(V_{T}\right)$ is estimated as $3.25 \mathrm{~km}^{3}$ DRE (Dense Rock Equivalent). Basal diameter / cone height values (Wco/Hco) and slope angles ( $\theta$ ) of the cones range between 3-39 and $2.3^{\circ}$ and $45^{\circ}$, respectively. Mean diameter I depth (Do/d) of maars changes between 8 and 40 . The total ejecta volume $\left(V_{E}\right)$ and total juvenile component volume (V) are estimated to be $0.36 \mathrm{~km}^{3}$ (DRE) and $0.34 \mathrm{~km}^{3}$ (DRE), respectively. The effusive activity from vents produced at least $2.3 \mathrm{~km}^{3}$ of basaltic lava flows. The total volume of all volcanic products is $\sim 5.9 \mathrm{~km}^{3}$. The morphological variance of cinder cones between $B-I I$ and $B$-III is due to the degradation rate.

Keywords: Alkali basalt, cinder cone, maar, lava flow, pyroclastic products, volumetric calculations, Kula Volcanic Field

\section{Giriș}

Türkiye, Alp-Himalaya Orojenik Kușağında yer almaktadır (Șekil 1). Geç Kretase-Eosen boyunca Neo-Tetis Okyanusu kapanarak (Șengör ve Yılmaz, 1981), Erken-Orta Miyosen zaman aralığında Anadolu Plakası ile Arap Plakası çarpıșarak Bitlis-Zagros Bindirme Zonunu olușturmaktadır (Șengör ve Yılmaz, 1981; Ring ve Layer, 2003 ve Okay vd., 2010). Bu çarpıșma sonrasında, Oligo-Miyosen'den itibaren Batı Anadolu'da yoğun bir kabuksal genleșme bașlamaktadır (Seyitoğlu ve Scott, 1991, 1992; Seyitoğlu vd., 2002; Sözbilir, 2002; Westaway vd., 2005; Koçyiğit, 2005; Bozkurt ve Mittwede, 2005; Ersoy ve Helvacı, 2007). Kabuksal genleșmeyi takiben Menderes Masifini olușturan metamorfik temel kayaçlar ortaya çıkmaktadır (Bozkurt ve Park, 1994; Lips vd., 2001; Gessner vd., 2001; Ring vd., 2003; Ișık vd., 2004; Sözbilir, 2005; Bozkurt ve Rojay, 2005; Ersoy vd., 2011 , 2012). Menderes Masifinin ortaya çıkması ile birlikte bölgede yaklașık D-B yönelimli Pliyosen-Kuvaterner yașı Simav, Gediz, Küçük Menderes ve Büyük Menderes grabenleri (Seyitoğlu, 1997a; Cohen vd., 1995; Emre, 1996; Hakyemez vd., 1999; Bozkurt ve Sözbilir, 2004; Rojay vd., 2005; Emre ve Sözbilir, 2007; Çiftçi ve Bozkurt, 2009) ve KD-GB yönelimli Miyosen yașlı Bigadiç, Gördes, Demirci, Selendi ve Ușak-Güre basenleri (Seyitoğlu ve Scott, 1991; Seyitoğlu ve Scott, 1994a ve b; Helvacı, 1995; Helvacı ve Yağmurlu, 1995; Seyitoğlu,1997b; Yılmaz vd., 2000; Bozkurt, 2003; Purvis ve
Robertson, 2004; Westaway vd., 2004; Erkül vd., 2005; Ersoy ve Helvacı, 2007; Seyitoğlu vd., 2009; Ersoy vd., 2010; Karaoğlu vd., 2010; Ersoy vd., 2011, 2012) meydana gelmektedir.

Kula Volkanik Alanı (KVA) Selendi Baseni içerisinde yer almaktadır. KD-GB yönelimli basenleri kapsayan bölgede, volkanizma bazı araștırıcılar tarafından kabuksal incelme ile ilișkilendirilmiștir (Yılmaz, 1989, 1990; Seyitoğlu, 1997b; Bunbury, 2001; Westaway vd., 2006; Ersoy vd., 2008; Karaoğlu vd., 2010). Bölgedeki volkanizma batıdan doğuya doğru, Bigadiç ve Ușak-Güre basenleri arasında kalan bölgedeki volkanizma Erken Miyosen yașlı yüksek-K içerikli kalkalkali dasitik ve riyolitik lav ve piroklastik ürünler ve șoșonitik, ultrapotasik lamproitler (Erkül vd., 2005; Ersoy ve Helvacı, 2007; Ersoy vd., 2011, 2012 ); Orta Miyosen yașlı yüksek-K içerikli kalkalkali dasitik, andezitik, yüksek-Mg içerikli șoșonitik, ultrapotasik lav ve piroklastik ürünler (Innocenti vd., 2005; Ersoy vd., 2008; Karaoğlu vd., 2010; Ersoy vd., 2011, 2012); Geç Miyosen yașlı K-trakibazaltları (Innocenti vd., 2005; Ersoy vd., 2011, 2012) ve Pliyo-Kuvaterner yașlı yüksek-Na içerikli bazaltik lav ve piroklastik ürünler (Tokçaer vd., 2005, Alıcı vd., 2002; Grützner vd., 2013) șeklinde yer almaktadır.

KVA'nın volkanizma öncesi stratigrafik istifi, alttan üste doğru șu șekilde sıralanmaktadır (Ercan vd., 1983; Bunbury, 1996; Seyitoğlu, 1997b; Purvis ve Robertson, 2005; Ersoy vd., 2007, 2011 ve 2012): (1) Temelde Menderes Masifinin Paleozoyik yașlı mikașist, kalksilikatik șist 


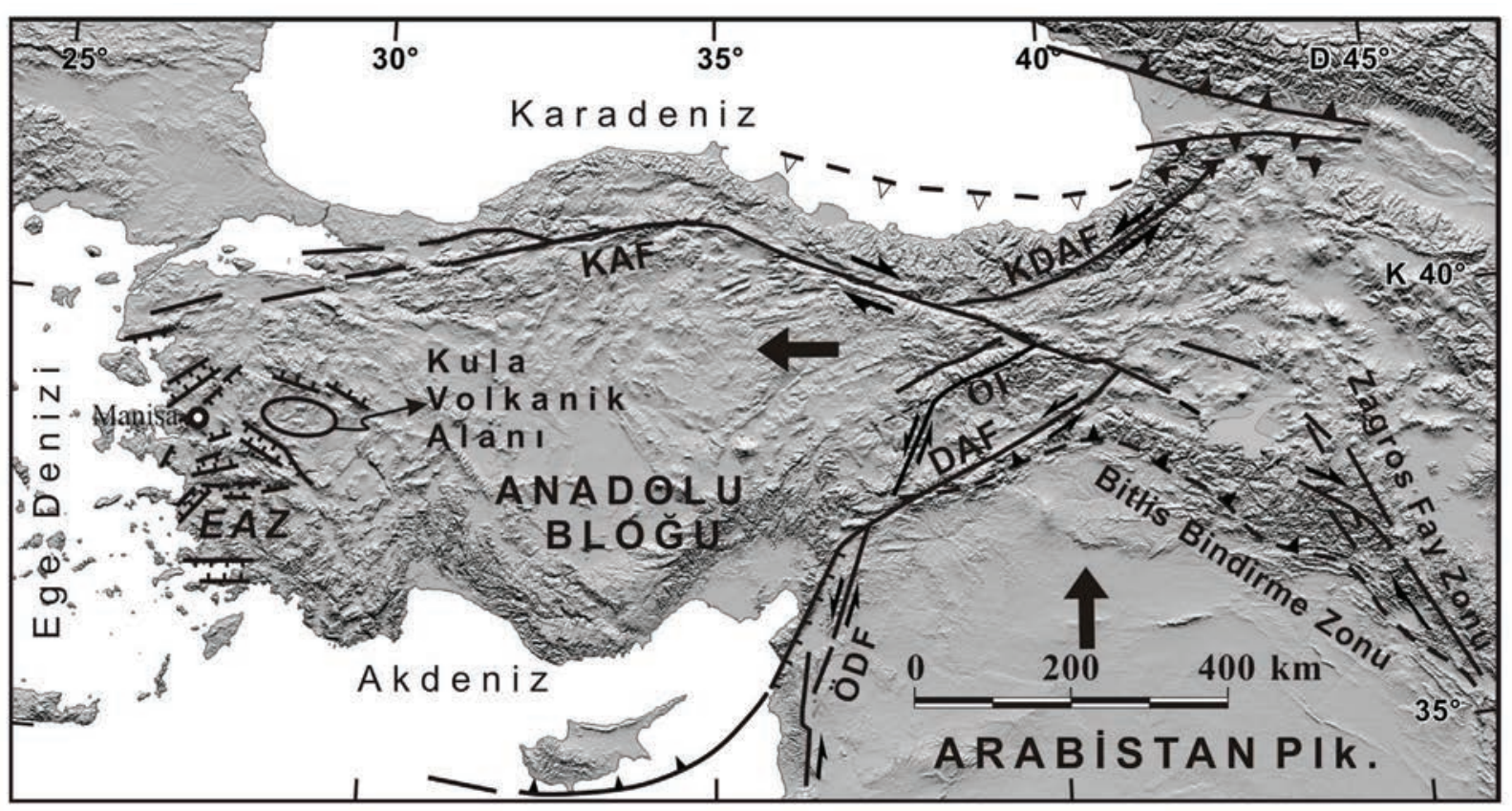

Șekil 1. Kula Volkanik Alanı ve Anadolu Plakası'nın neotektonik haritası (Șengör vd., 1985; Barka, 1992; Bozkurt, 2001'den basitleștirilerek alınmıștır). KAF: Kuzey Anadolu Fayı, DAF: Doğu Anadolu Fayı, KDAF: Kuzey Doğu Anadolu Fayı, OF: Ovacık Fayı, ÖDF: Ölü Deniz Fayı, EAZ: Ege Açılma Zonu.

Figure 1.Kula Volcanic Field and the neotectonic map of Anatolian block (Simplified from Șengör et al., 1985; Barka, 1992; Bozkurt, 2001). KAF: North Anatolian Fault, KDAF: Northeast Anatolian Fault, DAF: East Anatolian Fault, OF: Ovacık Fault, ÖDF: Dead Sea Fault, EAZ: Aegean Extension Zone.

ve gözlü gnayslarından olușan metamorfik kayaçlar, (2) Bindirme faylarla metamorfik temeli üzerleyen ve İzmir-Ankara Zonu kayaçlarına ait olan Geç Paleosen-Erken Eosen yașlı ofiyolitik melanj. Melanj içerisinde günümüzde halen aktif olan sıcak su kaynakları ve kaplıcalara yakın kesimlerde bulunan serpantinit ve lisvenit birimleri yer almaktadır (Șen, 2002). Hidrotermal bozunmanın yoğun olarak geliștiği bu kesimlerde zaman zaman yeșil-kahverengi çört katmanlarına, lisvenit içerisinde kalsedon damarlarına ve köken kayacı lerzolit olan serpantinitin içerisinde de yumrular halinde manyezit olușumlarına rastlamak mümkün olmaktadır (Șen, 2002), (3) Akarsu-gölsel çökeller: Kurtköyü Formasyonu (konglomera) ve üstte Yeniköy Formasyonu'nu (kumtașı - çamurtașı ardalanmalı) içeren Alt Miyosen yașlı Hacıbekir Grubu, (4) Hacıbekir Grubunu açısal uyumsuzlukla üzerleyen Orta Miyosen yașlı İnay Grubu. Altta konglomera ara katkılı, çoğunlukla kumtașı - kiltașı ardalanması șeklinde ilerleyen Ahmetler Formasyonu, ve üstte özellikle gölsel kireçtașı ve marn birimlerini içeren Ulubey Formasyonu bulunmaktadır. Bölgedeki peri bacaları Ahmetler Formasyonu'nda meydana gelmektedir. Peribacalarının șapkalarını kumtașı-kiltașı birimlerine göre, erozyona karșı daha dayanıklı olan konglomera katmanları olușturmaktadır (Șen, 2002).

Batı Anadoludaki Kula bazaltik volkanizması yaklașık $350 \mathrm{~km}^{2}{ }^{\prime}$ lik bir alana yayılmaktadır. Kula'daki volkanizma Burgaz, Elekçi Tepe ve Divlit Tepe olmak üzere 3 evreye ayrılmıștır (Ercan vd., 1983). Bunbury (2001) ise bazı yerel ikincil çökeller içerisinde Burgaz Evresi'nden daha yașlı bazaltik kayaç parçalarına rastlamıș ve bu ürünleri volkanostratigrafide birinci sıraya koymuștur. Monojenetik volkanların olușturduğu Kula bazaltik lavlarının hacmi yaklașık $2,3 \mathrm{~km}^{3}$ olarak tespit edilmiștir (Bunbury, 1996).

Kula volkanizması ile ilgili daha önce yapılan araștırmalar genellikle yapısal, petrolojik ve petrojenetik çalıșmalardır (Güleç, 1991; Bunbury, 1996; Seyitoğlu, 1997b; Aldanmaz vd., 2000; Alıcl vd., 2002; Purvis ve Robertson, 2005; 
Westaway vd., 2004; Tokçaer vd., 2005, Innocenti vd., 2005; Holness ve Bunbury, 2006; Westaway vd., 2006; Çoban, 2007; Ersoy vd., 2007, 2008; Karaoğlu vd., 2010; Ersoy vd., 2011, 2012; Grützner vd., 2013). Bu çalıșmanın amacını ise, lav akıntılarının ve piroklastik ürünlerin fiziksel özelliklerinin belirlenmesi vepüskürme merkezlerinin morfolojik tiplerinin incelenmesi olușturmaktadır. Bu verilere dayanılarak piroklastik ürünlerin hacimsel hesaplamaları da gerçekleștirilmiștir.

\section{VOLKANOLOJIK GELIȘiM}

KVA Türkiye'nin Batı Anadolu Bölgesi'ndeki Gediz Grabeni ile Simav Grabeni arasında bulunan Selendi baseninde yer almaktadır. KVA'da, yaklașık $35 \mathrm{~km}$ boyunca uzanan 64 cüruf konisi, fisüral çıkıșlarla ilișkili 16 küçük koni, 8 sıçratma konisi, 6 tümülüs ve 5 maar olmak üzere, toplam 99 monojenetik çıkıș merkezi bulunmaktadır. Detaylı arazi çalıșmaları ve volkanolojik haritalara göre, Kula volkanizmasının üç evrede gerçekleștiği tespit edilmiștir (Șekil 2). Kula volkanik ürünlerinin karasal ortamda yerleștiği gözönüne alındığında inceleme alanında gözlenen maarlar ve lokal olarak gerçekleșmiș yastık lav olușumları, volkanizmanın nehir, küçük su birikintileri ve yeraltı sularından da yer yer etkilendiğini göstermektedir.

İlk evre bazalt akıntılarına ait çıkıș merkezleri (bacalar) çok net olmamakla beraber, diğer bazalt akıntılarından topoğrafik olarak $170 \mathrm{~m}$ daha yüksekte bulunmaktadır. Bölgede en yaygın volkanizma II. Evre bazalt akıntılarıdır. Bu evrede yer yer freatomagmatik patlamalar meydana gelmiștir. Son Evre bazalt akıntıları çok taze morfoloji sunmaktadır ve II. Evre bazalt akıntılarının volkanik çıkıș merkezlerine paralellik göstermektedir. Muhtemelen, çıkıș merkezleri değișse de aynı kırık ve fay sistemini takip etmișlerdir.

\section{Evre Bazalt Akıntıları (Burgaz, B-I):}

Çalıșma alanının sadece doğu kesimlerinde izlenen evrenin $\mathrm{K} / \mathrm{Ar}$ (hamur) ve $\mathrm{Ar} / \mathrm{Ar}$ (amfibol) radyometrik yașı 1,94 $\pm 0,16$ My ile 0,99 $\pm 0,11$ My arasında değișmektedir (Borsi vd., 1972;
Bunbury, 2001; Westaway vd., 2004 ve 2006). Çalıșma alanının, en yașlı bazaltik ürünü olan I. Evre bazalt akıntıları, Ahmetler Formasyonu'na ait konglomera ara katkılı, kumtașı-kiltașı ardalanmasının üzerine yerleșmiștir. Dokanağın gerçekleștiği yerlerde zaman zaman pișme zonu gözlenmektedir. Lav akıntıları koyu gri-siyah renkte olup, yaklașık $35 \mathrm{~km}^{2}$ 'lik bir yüzey alanına sahiptir (Șekil 2). Arazide genellikle dik yamaçlı bir morfoloji sunan bu akıntılar, soğumaya bağlı çok iyi gelișmiș sütun yapıları sunmaktadır (Șekil 3a). Akıntıların kalınlığı 10-30 m arasında değișmekte olup, ortalama kalınlık 15 m olarak tespit edilmiștir. Oldukça masif bir görünüme sahip olan B-ı bazaltların gözeneklilik oranı \% 3'ten küçüktür (Șen, 2002). Fisüral çıkıșlar plato bazaltlarının en karakteristik özelliklerinden olup, çok sayıda merkezden yayılım gerçekleșebilir (Tyrrell, 1932; Galindo ve Gudmundsson, 2012). Șekil 3b' de bu çıkıșlardan biri gösterilmektedir.

\section{Evre Bazalt Akıntılar (Elekçi Tepe, B-II):}

II. Evre bazaltlarının K/Ar (hamur ve amfibol) radyometrik yașları 299 bin \pm 20 yıl ve 50 bin \pm 9 yıl arasında değișmektedir (Bunbury, 2001; Westaway vd., 2004 ve 2006). Ürünler, genellikle toprak örtüsü tarafından örtülmüș olup, koyu mavigri renklerdedir. B-II bazaltları en iyi yüzleğini, İbrahimağa Köyü, Dereköy-Gediz Nehri kenarı, Evci Mahallesi civarında vermektedir. Kalınlığı 3-15 m arasında değișen bazaltik akıntının ortalama kalınlığı 8 m'dir. Çıkıș merkezlerini 49 koni, 4 maar ve 1 adet fisür olușturmaktadır. Yayılan akıntının yüzey alanı $235 \mathrm{~km}^{2}$ yi bulmaktadır. Akıntılar, kuzeyden güneye doğru, ortalama $5^{\circ}$ eğimle akmıșlardır. Akıntı temelindeki parçalanmalar veya akma breși altındaki formasyonlarla keskin bir dokanak olușturmaktadır. Kaynaktan olan uzaklık arttıkça, akıntının kalınlığı 1-2 m'ye düșmekte ve temelindeki akma breși yerini bazı yerlerde masif bir görünüme terketmektedir.

Gözeneklilik, akıntının temelinde, özellikle breșleșmiș kısımlarında ve akıntının üst kısmındaki bloklașmıș kesimlerde artmaktadır. Orta kısımlar ise, daha masif veya tıkız bir yapıya sahiptir. Gözenekler alt ve orta kısımlarda yuvarlağımsı șekilli, orta kısımlarda ise soğuma yüzeyine 


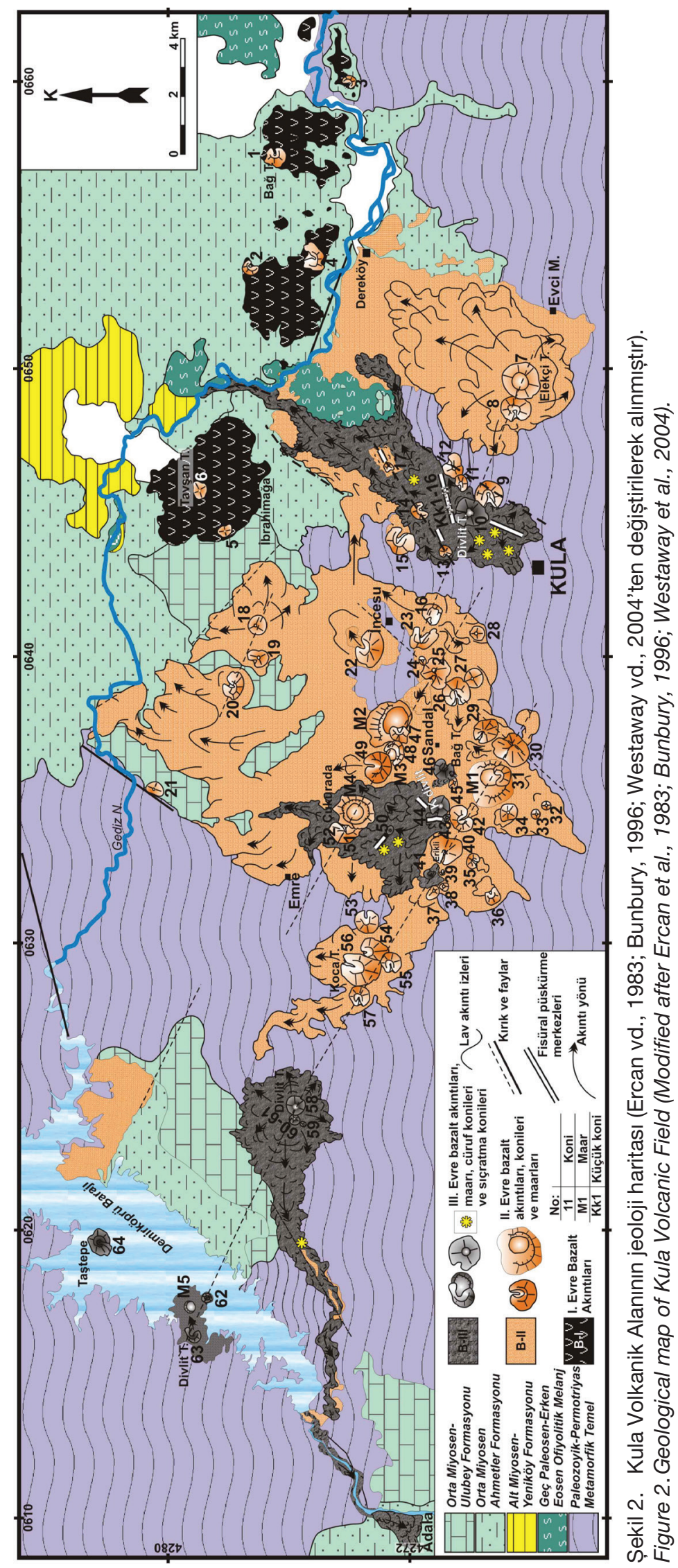




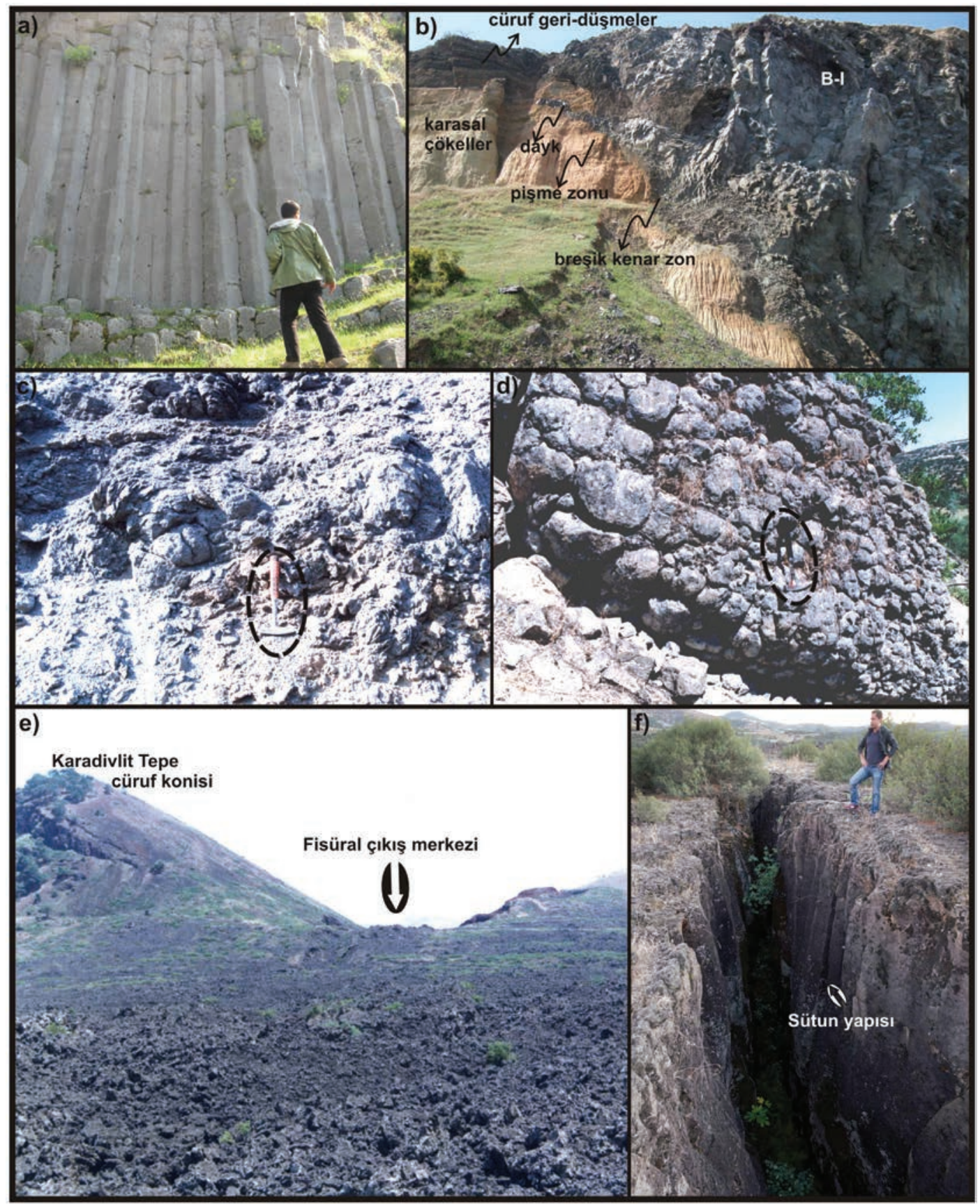

Șekil 3. Kula lavlarına ait arazi resimleri: a) B-I bazaltlarına ait sütun soğuma yapıları, b) B-ı bazaltlarına ait bir çıkıș merkezi. Lav çıkıșı öncesinde zayıf patlamalara bağlı olarak cüruf geri-düșme ürünleri olușmuștur. Sokulum çevre kayaçlarda pișirme zonu olușturmuș ve dokanakta breșleșmeye uğramıștır. Ayrıca küçük bir çatlak içerisine de yerleșerek dayk meydana getirmiștir, c) B-Il lav önüne ait soğan kabuğu bozunma yapıları, d) B-II bazaltlarının su ile teması sonucu gelișmiș yastık yapılı lavları, e) Karadivlit Tepe'nin yakınındaki fisürden çıkan a'a tipli B-III lavları, f) Gediz Nehri’ne parallel (K-G) olarak gerçekleșen yaklașık 1 km uzunluğundaki kırık.

Figure 3.Photographs from the fieldwork: a) Columnar joint structures of B-I basalts, b) An eruptive center of the $B-I$ basalts. Scoria ash fall deposits occurred because of weak explosion before eruption of lava. Intrusion resulted in a cooked zone and brecciated along the contact. In addition, it settled into a small crack as a dike, c) Onion-like alteration on the lava front, d) Pillow lavas of B-Il basalts resulted from contacting the water, e) 'a'a lava type of the B-III basalt erupted from a fissure near Karadivlit Tepe, g) A fracture about $1 \mathrm{~km}$ in length parallel to the Gediz River (NS) 
paralel, basık, ince, uzun șekillidirler. Akıntılar, metamorfik kayaçlardan kopartılmıș ksenolitler içermektedir. Bazı akıntı birimleri, tabakalı akma yapıları göstermektedir. Rengi, koyu gri olan bu kesimler, kristalce daha zengindir. Akıntının üst seviyelerine gidildikçe kısmen sütunsal yapılar ve çoğunlukla masif bir görünüm sunmaktadır. Üst kısımlar bloklu yapıda olup, renk açılmakta ve kristal oranı düșmektedir.

Volkanik faaliyetlerin en yaygın olduğu bu evre, doğal olarak Kula volkanizması'nın en büyük hacimli ve yayılımlı ürünlerini temsil etmektedir. Illk faaliyetler zayıf enerjili patlamalarla bașlamıș ve özellikle Evci Mahallesi yakınlarında kalınlığı 30-40 cm'yi bulan cüruf geri-düșme ürünlerini olușturmuștur. Buradaki litik bileșenlerin camsı olması patlamanın bir miktar su ile etkileșime geçtiğini göstermektedir. II. Evre bazalt akıntılarının, B-I bazaltlarından genç olmasına rağmen, fiziksel olarak daha fazla bozunma geçirdiği dikkat çekmektedir. Özellikle akıntı önlerinde soğan tipi bozunmalar yaygın olarak izlenmektedir (Șekil 3c). Gediz Nehri kenarlarında yer yer su ile karșılaștığını gösterir küçük ölçekli yastık lavlar (Șekil 3d) ve köșeli, sivri uçlu ayrılmaların gerçekleștiği ani soğuma yapıları görülmektedir. Lavın suyla karșılaștığı bu ortamlarda, soğuma hızından dolayı, akıntının dıș kısımları camsı bir görünüm sunmaktadır.

Bu evre bazalt akıntıları içinde, ultramafik ve mafik anklavlar (kümülatlar) gözlemlenmektedir. Özellikle piroklastik ürünlerin içerisinde yer alan bu anklavlar, lerzolit, verlit, piroksenit, hornblendit (bol miktarda), piroksenli hornblendit, hornblendli piroksenit, gabro olarak adlandırılmıștır (Çakır vd., 1999; Șen, 2002; Holness ve Bunbury, 2006; Grützner vd., 2013). Anklavların en önemli özelliği gözenekli olmaları ve volkan camı içermeleridir. Büyük bir kısmı iri mineralli olduğu için hornblend ve piroksen mineralleri kolaylıkla ayırt edilebilmektedir. Anklavların yanı sıra, mikașist, mikagnays ve kiltașı gibi ksenolitlere de rastlanılmıștır.

\section{Evre Bazalt Akıntıları (Divlit Tepe, B-III):}

Üzerinde toprak olmayan ve az bitki örtüsü olan son evre bazalt akıntıları oldukça taze bir görünüm sunmaktadır. Kula volkanizmasının son ürünleri olan III. Evre $26 \pm 5$ bin yıl ile 4 bin \pm 2 yıl (K/Ar-hamurdan ve termolüminesans yöntemi ile) arasında faaliyet göstermiștir (Göksu, 1978; Westaway vd., 2004, 2006). Bu evredeki lav akıntılarının çıkıș merkezlerini 30 cüruf konisi, 8 sıçratma konisi, 6 tümülüs ve 5 önemli sayılabilecek fisür olușturmaktadır. Bölgenin batı kısmındaki lav akıntıları, vadiyi 17 km kadar takip ederek Adala kasabasına kadar gelmiș ve batı-güneybatı yönünde akmıșlardır. Çalıșma alanının ortasındaki akıntı, kuzey yönünde $7 \mathrm{~km}$, en doğudaki akıntı ise güneybatı yönünde $3 \mathrm{~km}$ ve kuzeydoğu yönünde ikiye ayrılarak $10 \mathrm{~km}$ ve $7 \mathrm{~km}$ akabilmiștir (Șekil 2). Yaklașık olarak 85 $\mathrm{km}^{2}$ lik bir alana yayılan III. Evre bazalt akıntılarının kalınlığı 3 ile $10 \mathrm{~m}$ arasında olup, ortalama kalınlığı 8 m olarak tespit edilmiștir.

Lav çıkıș noktalarını olușturan fisürlerin uzunluğu 20 ile 400 m arasında değișmektedir. Bu fisürlerin büyük çoğunluğu graben sisteminin doğrultularına paralellik göstermektedir. Șekil 3 e'de Karadivlit Tepe'nin hemen batısında bulunan bir fisür erüpsiyonu görülmektedir. Uzunluğu 50 m kadar olan çatlağın her iki yamacında lav akıntıları mevcuttur. Aynı bölgede buna benzer bir kaç yarık daha bulunmaktadır.

B-III bazaltları 'a'a tipi lav akıntısı morfolojisindedir. Yüzeyi son derece sivri, karmașık ve köșeli bloklardan olușmaktadır. Ancak kaplıca bölgesinin yakınlarında B-III bazaltlarını kesen ve yaklașık K-G doğrultulu genișliği $6 \mathrm{~m}$ ve derinliği en az 8 m'yi bulan, yaklașık $1 \mathrm{~km}$ uzunluğunda bir çatlak bulunmaktadır (Șekil 3f). Bu kusursuz çatlak B-III bazaltlarının iç kısmını görmemize imkan sağlamıștır. Buna göre, son evrenin bazalt akıntısı tipik olarak üç kısımdan olușmaktadır: Alt seviye; breșleșmiș ve çeșitli parçalanmalara maruz kalmıștır. Kalınlığı 30 ile $90 \mathrm{~cm}$ arasında değișmektedir. Akıntı, Gediz Nehri'nin açmıș olduğu vadi kenarlarında suyla karșılașmıș ve akıntının temeli aniden soğuyarak camsı bir görünüm kazanmıștır. Orta seviye ile arasında keskin bir geçiș bulunmaktadır. Gözenek hacmi 1 ile $3 \mathrm{~mm}$ arasında değișmektedir. Gözenek hacmi tabandan üste doğru gittikçe artmakta, orta seviyeye yaklașırken azalmaya bașlamaktadır. Gözeneklilik miktarı ise azalmaktadır. Orta seviyede iyi gelișmiș sütun soğuma yapıları bulunmaktadır. Poligon çapları 
bazı yerlerde $50 \mathrm{~cm}$ 'yi bulmaktadır. Sütun bölgesinin kalınlığı 2 ile $6 \mathrm{~m}$ arasında değișmektedir ve gözenekliliğin en az olduğu masif kısmı temsil etmektedir. Buradaki gözeneklerin çapı maksimum 10 mm'yi bulmaktadır. Çoğunlukla silindirik șekillidirler. En üst seviye ise, kalınlığı 1 ile $3 \mathrm{~m}$ arasında değișen bloklanmıș kısımlardan olușmaktadır. Bazı seviyeler oldukça gözenekli olup köpüğümsü bir görünüm sunmaktadır. Bu seviyedeki gözenekler, $1 \mathrm{~mm}$ ile $30 \mathrm{~mm}$ arasında değișmektedir. Gözenekler çoğunlukla dairesel-oval șekle sahip olup, yüzeye yakın kesimlerde yaklașık eșit boyuttadırlar. Bazı kesimlerde üst seviyeden bir alt seviyeye geçiș tedrici olurken, bazen de çok keskin olmaktadır.

\section{MONOJENETIK PÜSKÜRME MERKEZLERI}

Bölgede 64 cüruf konisi, haritalanamayacak ölçekte 16 küçük cüruf konisi, 8 sıçratma konisi, 6 tümülüs ve fisüral püskürme merkezleri bulunmaktadır. Monojenetik yapıların diziliși Selendi basenindeki KD-GB ve Gediz Grabeninin KBGD gerilme yönlerine uyumluluk göstermektedir. Taban çapları $100 \mathrm{~m}$ ile 1,3 km arasında değișmektedir. Konilerden bazıları çift kratere sahip olup, uzunlamasına (elipsoyidal) șekle sahiptir. Bir kaç çıkıș merkezi sonraki ürünlerce örtülmüștür (Bunbury, 1996).

\section{Cüruf Konileri}

Kula volkanizmasının tanık olduğu en önemli püskürme merkezleri, batıda Taștepe, Divlit Tepe'ler, Küçükdivlit Tepe ve Koca Tepe; orta bölgede Bağtepesi konileri, Bağtepe, Karadivlit Tepe, Erikli Tepe, Kaymakçı Tepe, Erikli Tepe'ler, Divlit Tepe ve Kestaneli Tepe; batıda ise Hacıbasan Tepe, Elekçi Tepe, Bağtepedir.

KVA'da stromboliyen tip püskürmeler sonucu olușan koniler, normal ve karnıyarık olarak iki morfoloji sunmaktadırlar (Șekil 4a ve b).

Doğu'da Divlit Tepe'nin kuzeyinde III. Evreye ait olan ve fisüral püskürme sonucu olușan, taban çapları 100 ile $150 \mathrm{~m}$ ve yükseklikleri 10 ile 30 $\mathrm{m}$ arasında değișen toplam 16 adet cüruf konisi bulunmaktadır. Özellikle elipsoyidal șekilli konilerin yaygın olduğu bu bölge, küçük bir koni topluluğu görüntüsü vermektedir (Șekil 4c).
Kula bölgesindeki cüruf konilerin ürünleri tefra ve lav akıntıları olmak üzere iki șekildedir (Șekil 4d). Cüruf konilerini olușturan piroklastikler; cüruflar, litikler ve elipsoyidal bombalar șeklinde meydana gelmișlerdir. Ürünlerin tane boyu, kül ile $3 \mathrm{~m}$ çaplı bombalar arasında değișmektedir (Șekil 4e). Koni içerisinde yer alan ürünler kırmızı ve siyah renkli tabakalanmalar șeklinde bulunmaktadır. Bazı koniler, cüruf ürünlerinin yanı sıra onlarla ardalanmalı olarak gelișen lav katmanlarını içermektedir.

\section{Maarlar}

KVA'da 5 adet maar bulunmaktadır. Maarlardan sadece Çukurada (Șekil 2: M4) kendi ismiyle adlandırılmıștır. Diğerleri, sahip oldukları ve maar kenarından çıkan cüruf konilerinin isimleriyle adlandırılmıștır (Șen, 2002). Krater çapları $875 \mathrm{~m}$ ile $1125 \mathrm{~m}$ arasında değișmektedir. Çukurada Maarı hariç geri kalan tüm maarlar oluștuktan sonra meydana gelen freatomagmatik faaliyetler, krater kenarından çıkan cüruf konileriyle magmatik faaliyete dönüșmüș, volkanolojik evrim bu șekilde tamamlanmıștır. Maarlardan Divlit Tepe Maarı (M5) III. Evre'ye aitken, diğerleri II. Evre'de meydana gelmișlerdir.

Kula bölgesinde olușum mekanizmasına göre (Cas ve Wright, 1987) 'maar' ve 'tüf halkası' olarak tanımlanabilecek iki maar türü bulunmaktadır. Birinci türü Çukurada Maarı temsil etmektedir (Șekil 5a); patlama sonucu 110 m derinliğinde bir krater olușmuștur. Krater tabanı genel topoğrafik yüksekliğin altındadır. Krater çeperlerinde patlama sırasında var olan lav akıntıları yüzlek vermektedir. Patlama ile olușmuș taban yayılımı ürünleri içerisinde ise bu kayaçlara ait litikler bulunmaktadır. Çalıșma alanının orta kısmında bulunan maarın batı kenarında Ada Tepe cüruf konisi bulunmaktadır. Morfolojik olarak maar kenarından çıkan bir cüruf konisini andırmaktadır. Ancak, koninin cüruf geri-düșme ürünleri Çukurada Maarı'na ait ürünler tarafından örtülmektedir. Kula bölgesinde 'tüf halkası' tipindeki ikinci tür maar olușumlarına örnek olabilecek 4 maar bulunmaktadır (Șekil 2): Yağbasan Tepe (M1), Cemal Tepe (M2; Șekil 5b ve c), Kızıl Tepe (M3) ve Divlit Tepe (M5). Divlit Tepe (M5) hariç, her tüf halkasının kenarında bir cüruf 


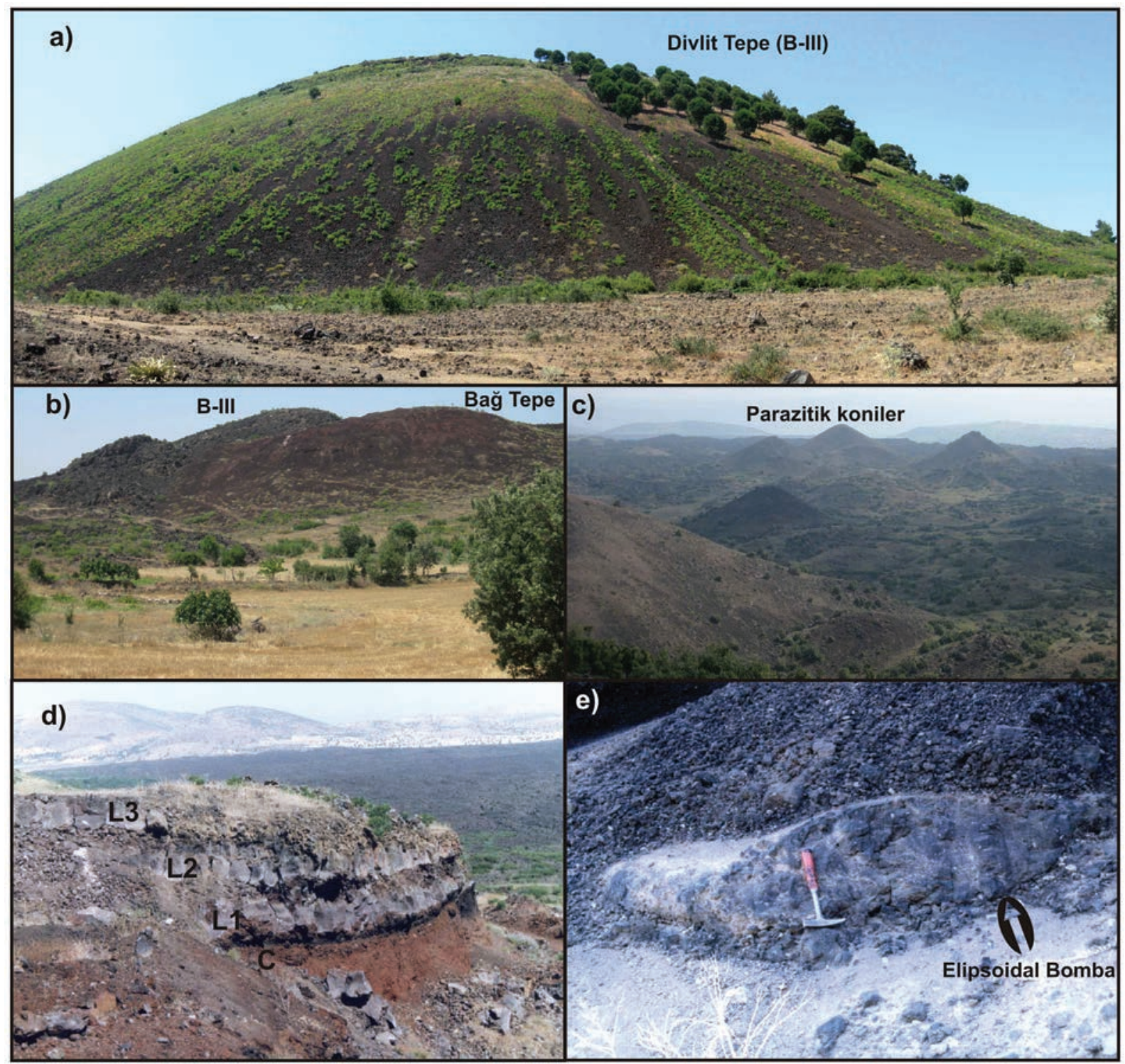

Șekil 4. Cüruf konileri ve ürünleri. a-b) Sandal'ın batısında yer alan Divlit Tepe cüruf konisi ve kraterinden a'a tipi lav çıkmıș Bağ Tepe karnıyarık cüruf konisi, c) Kula'nın yakınında yer alan Divlit Tepe'nin kuzeyindeki parazitik koniler, d) Karadivlit Tepe'ye ait, altta cüruf geri-düșme ürünleri (C) ve üstte onu üzerleyen 3 katman halindeki (L1-L3) lav akıntıları. Her lav katmanının tabanında akma breșleri yer almaktadır, e) Cüruf konisi içerisinde görülen ellipsoyidal bomba.

Figure 4. Cinder cones and their products: a-b) Karadivlit Tepe cinder cone and breached Bağ Tepe cinder cone with 'a'a type lava flows erupted from its crater in the west of Sandal, c) Parasitic cones in the north of Divlit Tepe near Kula, d) Scoria air-fall deposits (C) overlain by three layers of lava flows (L1-L3). Each layer has flow breccia at the base, e) Fusiform bomb in a cinder cone.

konisi meydana gelmiștir. Tüf halkalarının krater taban seviyeleri yer seviyesinin üzerinde bulunmaktadır. Derinlikleri 33 m ile 65 m arasında değișmektedir.

Freatomagmatik faaliyetlere ait taban yayılımı ürünleri, $\mathrm{cm}$ ve dm ölçeğinde kül katmanları șeklinde depolanmıșlardır. Bu katmanlar, çok iyi gelișmiș kumul tepecikleri (dune, anti-dune) ve çarpma-çökme yapıları (bomb-sag) içermektedir (Sheridan ve Wohletz, 1983; Wohletz ve McQueen, 1984; Fisher ve Schmincke, 1984; Cas ve Wright, 1987; Manga vd., 2012) (Șekil 

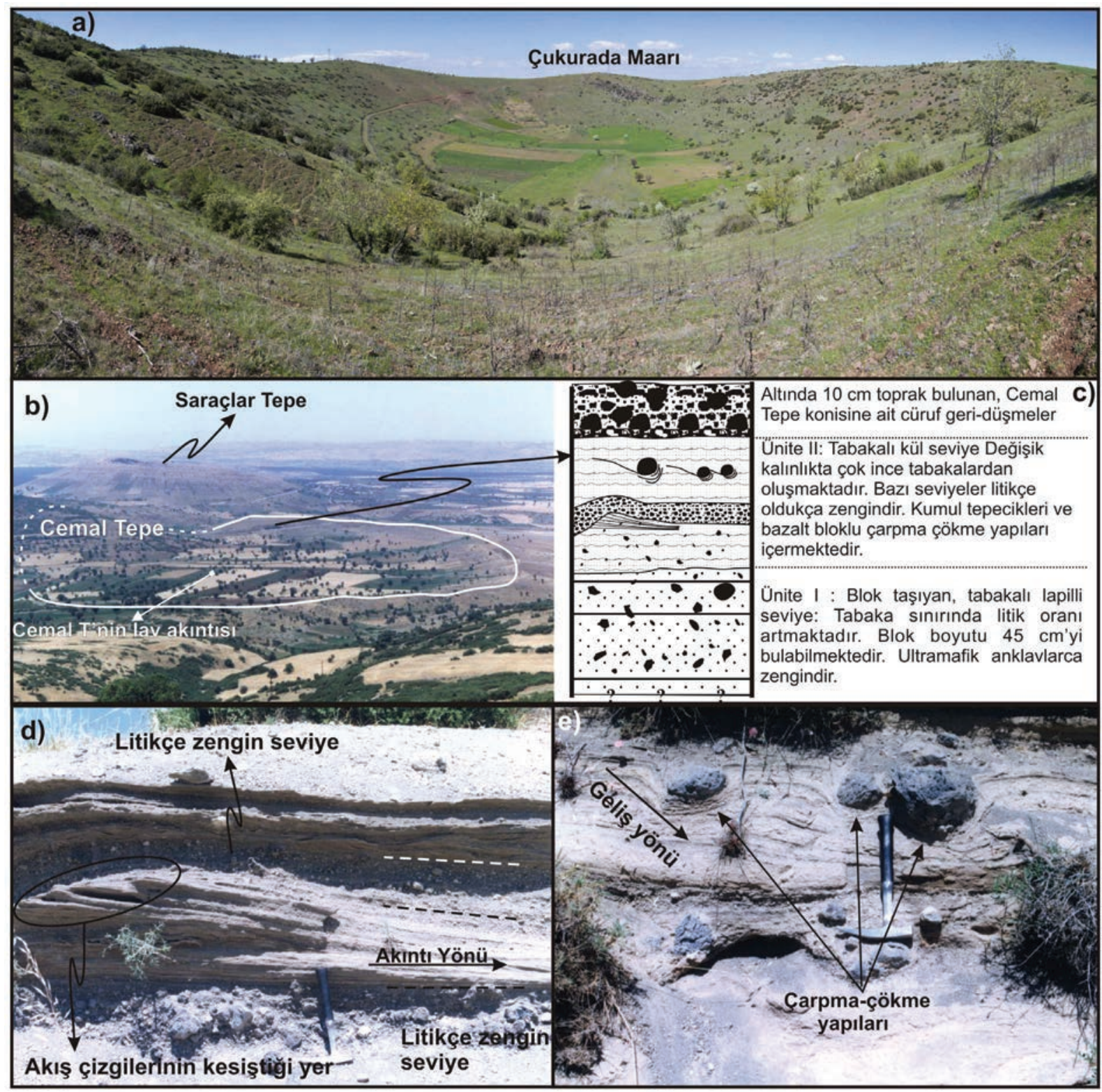

Șekil 5. Maarlar ve ürünleri. a) Çukurada maarı, b) Cemal Tepe tüf halkası. Krater sınırı beyaz çizgi ile gösterilmiștir, c) Cemal Tepe tüf halkasına ait taban yayılımı kesiti, d) Çapraz tabaka yapısı sunan ve akma yönünü gösteren, taban yayılımı ürünlerine ait kumul tepesi yapısı, e) Kaynak yönü gösteren, taban yayılımı içerisinde gözlenen çarpma-çökme yapıları

Figure 5. Maars and their deposits: a) Çukurada maar, b) Cemal Tepe tuff ring. White line indicates crater rim, c) Cross section of the base surge deposits for Cemal Tepe tuff ring, d) Dune-anti dune structure crossbedded showing flow direction, e) Bomb-sags indicating source direction (arrowed) for the base surge deposits.

$5 d$ ve e). Yağbasan ve Cemal Tepe tüf halkasındaki freatomagmatik ürünler, cüruf projeksiyonları ile ardalanmalı olarak bulunmaktadır. Özellikle Çukurada Maarı'na ait taban yayılımı ürünleri, krater kenarında, eğimleri merkeze doğru olan normal atımlı faylarla kesilmișlerdir. Taban yayılımı ürünlerini karakterize eden bileșenlerden biri de yığıșım lapillileridir (Buettner ve Zimanowski, 1998). Bir çekirdek (çok ince taneli kristal, cüruf veya litik) etrafına ıslak külün 
yapıșıp, genellikle küresel geometride yığıșarak büyümesi sonucunda olușan bu lapilliler (Schumacher ve Schmincke, 1991) sadece Divlit Tepe tüf halkasında (M5) bulunmaktadır.

Demirköprü baraj gölü batısında bulunan M5 tüf halkasına ait taban yayılımı ürünlerinin üzerinde fosil insan ayak izleri bulunmuștur. Bu izler Divlit Tepe konisinden gelen cüruf geri-düșme ürünleri tarafından örtülerek günümüze kadar, așınmadan korunabilmișlerdir. Ayak izlerinin bulunduğu birimin termolüminesans yașı $26 \pm$ 5 bin yıl olarak bulunmuștur (Göksu, 1978). Ancak, Erinç (1970) ve Tekkaya (1976) ayak izlerinin yașlarını yaklașık 12 bin ve 10 bin yıl olarak tahmin etmektedirler.

\section{Sıçratma Konileri ve Tümülüsler}

Kula bölgesinde çoğunlukla lav ve zaman zaman da cüruf püskürmelerinin gerçekleștiği bu çıkıș merkezleri sadece III. Evre'de meydana gelmișlerdir. Sıçratma konileri dairesel bir yapıya sahip olup, oldukça eriyik haldeki lavın bir çatlak boyunca, çıktığı yerde katılașarak veya lav akıntısının soğuyarak katılașan kabuğunun çöküp, alttaki sıcak ve akıșkan lavın bu merkezden çıkmasıyla olușmaktadır (Macdonald, 1972; Rossi ve Gudmundsson, 1996) (Șekil 6a). Bu tür yığıșımlar hem birincil çıkıș merkezlerinde hem de ikincil (köksüz) çıkıșlarda meydana gelebilirler. Kula yakınındaki Divlit Tepe'nin hemen güneyinde yer alan sıçratma konileri fisür siste-

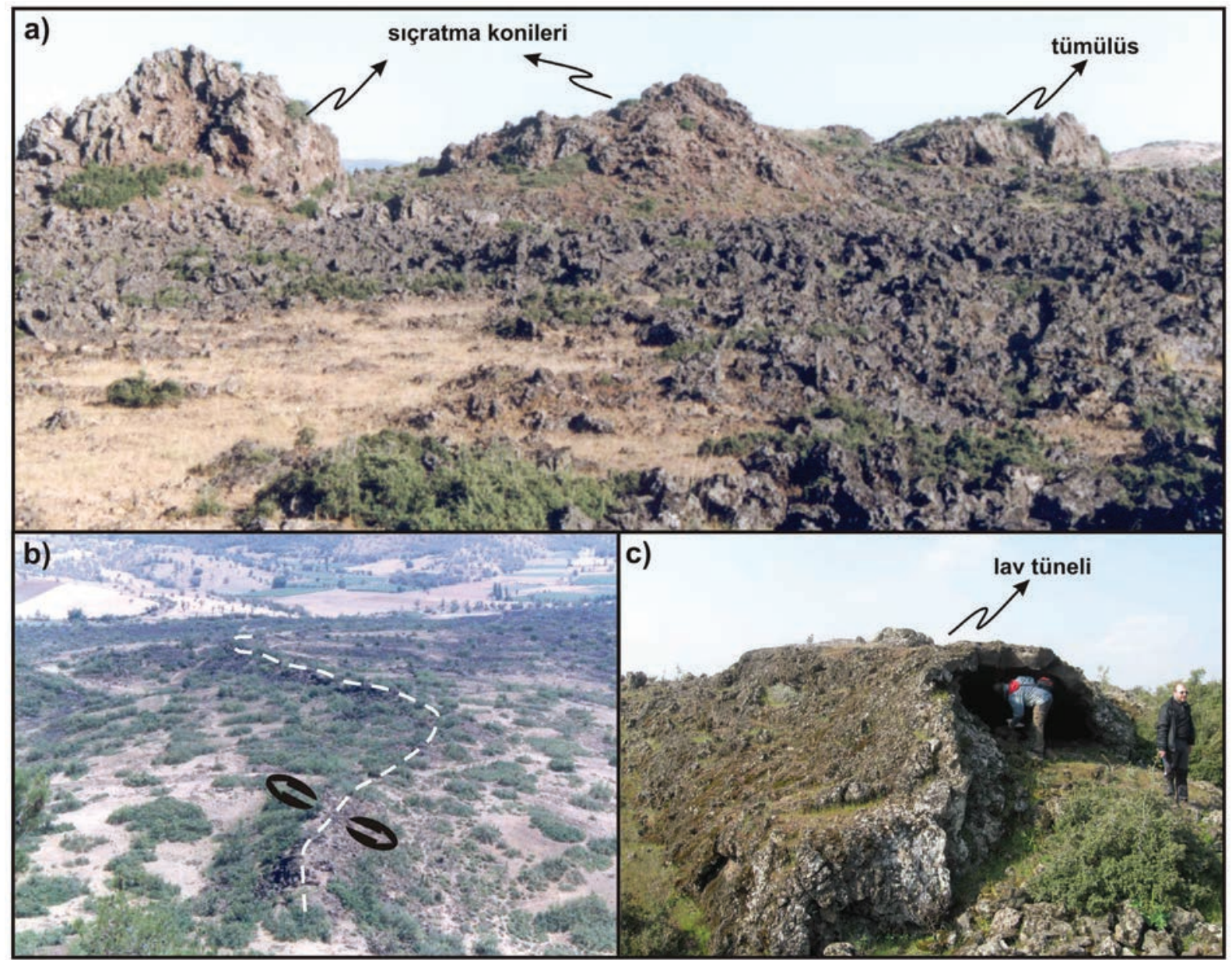

Șekil 6. a) Sıçratma konileri ve tümülüs, b) Kesikli beyaz çizgi ile gösterilen bir fisür. Bu fisür boyunca püskürmelere bağlı olarak gelișmiș, 1-2 m yüksekliğinde sırt olușmuștur, c) Lav tüneli

Figure 6. a) Spatter cones and tumulus, b) A fissure indicated with white dashed line. A ridge of 1-2 $m$ in height along the fissure occurred due to the eruption, c) Lava tunnel 
minin içerisinde yer aldığı için, hepsinin birincil çıkıș merkezlerinde meydana geldikleri düșünülmektedir. Ancak, Çukurada Maarı'nın güneybatısındaki sıçratma konisi için, lavların yoğun çıkıș merkezlerine uzak olması nedeniyle aynı șeyleri söylemek mümkün olmayabilir. Sıcak ve düșük viskozite özelliklerine sahip olan lav sıçratmalarının olușturduğu konilerin yükseklikleri 7-15 m arasında değișmektedir. Eğer lav sıçratmaları bir fisür boyunca gerçekleșirse yüksekliği 3-4 m'yi bulan sırtlar da olușabilmektedir (Șekil 6b). Püsküren lav oldukça sıvı olup, çatlağın her iki yanına doğru bir set olușturarak yığılma yapmaktadır. Oldukça sıcak oldukları için çıkan lav kütleleri birbirine yapıșı halde bulunmakta ve yana doğru yayılmaktadırlar. Bu tür akıntılarda lav kütlesinin yüzeyi atmosferle temas ettiği için iç kısma göre daha hızlı soğumaktadır. Alttaki magma daha sıcak olduğu için üst kısma göre akıșkanlığı fazla olmakta ve akmaya devam etmektedir. Üstte hızlı soğuma nedeniyle katılașan kabuk eğer yeteri kadar kalın ve sağlam ise çatısını koruyarak altında lav tüneli olușturmaktadır (Dragoni vd., 1995; Keszthelyi ve Self, 1998; Dragoni ve Santini, 2007) (Șekil 6c). Ancak, III. Evre'de lav tüneli olușumlarından ziyade lav kanallarına rastlamak daha olasıdır.

Tümülüsler, önceden akmıș ve tamamen veya kısmen katılașmıș olan lavın alttan daha sonra gelen eriyik haldeki lav ile yukarı itilmesi sonucu kazanmıș olduğu tümseğimsi (hummocky) bir topografya șeklinde tanımlanmaktadır (Șekil 6a; Macdonald, 1972; Rossi ve Gudmundsson, 1996). Üst kabuğun yerinden oynatıması sonucu tümülüsün orta kısmında bir çatlak olușur. Genellikle sıçratma konileri ile birlikte bulunan tümülüsler diğer monojenetik çıkıș merkezlerinin yer aldığı ana kırık sistemine de uyumluluk göstermektedir.

\section{PETROGRAFI VE JEOKIMYA}

Illk petrografik çalıșmalar Washington (1900) tarafından yapılmıș ve hornblend minerali ile karakterize edilen Kula bazaltlarına "Kulait" adı verilmiștir. Kula bazaltlarının mineralojik bileșimleri Çizelge 1'de özetlenmiștir. Hornblendlerin varlığı II. Evre ile bașlamaktadır.. Tüm lav ürünleri porfirik dokuya sahip olup, olivin ve klinopiroksen mineralleri yaygın olarak görülmektedir. Bazaltlar içindeki minerallerin oranları oldukça değișkendir. Plajiyoklaz, genellikle mikrolit olarak izlenmektedir. Lösit, nefelin gibi alkali mineraller, hem fenokristal olarak, hem de hamur içerisinde mikrolit olarak gözlenmektedir. Oksit mineralleri (opak mineraller), tüm evrelerde, hamurda içerisinde, bol miktarda yer almaktadır. Hamurda açık renkli minerallerin mikrolitleri yanı sıra, olivin, klinopiroksen ve hornblend

Çizelge 1. Kula volkanik ürünlerine ait mineral birliktelikleri (OI: olivin, Klp: klinopiroksen, Hb: hornblend, PI: plajiyoklaz, Ne: nefelin, Lö: lösit)

Table 1. Mineral assemblage of the Kula volcanic products (Ol: olivine, Klp: clinopyroxene, Hb: hornblende, Pl:, plagioclase, Ne: nepheline, Lö: leucite)

\begin{tabular}{|c|c|c|}
\hline EVRE & Fenokristaller & Hamur \\
\hline I. Evre (B-I) & $\mathrm{OI}+\mathrm{Klp}$ & $\mathrm{Ol}+\mathrm{Klp}+\mathrm{PI}+\mathrm{Lö}$ \\
\hline \multirow[t]{4}{*}{ II. Evre (B-II) } & $\mathrm{Klp}+\mathrm{Hb}+\mathrm{Lö}$ & $\mathrm{Klp}+\mathrm{Hb}+\mathrm{PI}$ \\
\hline & $\mathrm{Ol}+\mathrm{Klp}+\mathrm{Hb}+\mathrm{Ne} \pm \mathrm{PI}$ & $\mathrm{Ol}+\mathrm{Klp}+\mathrm{Hb}+\mathrm{PI}$ \\
\hline & $\mathrm{OI}+\mathrm{Klp}+\mathrm{Hb}+\mathrm{Lö}$ & $\mathrm{Ol}+\mathrm{Klp}+\mathrm{Hb}+\mathrm{Lö+PI}$ \\
\hline & $\mathrm{Ol}+\mathrm{Klp}+\mathrm{Hb}+\mathrm{Ne}+\mathrm{Lö}$ & $\mathrm{Klp}+\mathrm{Pl}+\mathrm{Hb}+\mathrm{Lö}$ \\
\hline \multirow[t]{4}{*}{ III. Evre (B-III) } & $\mathrm{Ol}+\mathrm{Klp}+\mathrm{Hb}$ & $\mathrm{Ol}+\mathrm{Klp}+\mathrm{Hb}+\mathrm{Pl} \pm \mathrm{Ne} \pm \mathrm{Lö}$ \\
\hline & $\mathrm{Ol}+\mathrm{Klp}+\mathrm{Hb}+\mathrm{Ne} \pm \mathrm{PI}$ & $\mathrm{Ol}+\mathrm{Klp}+\mathrm{Hb}+\mathrm{Ne}+\mathrm{PI}$ \\
\hline & $\mathrm{Ol}+\mathrm{Klp}+\mathrm{Hb}+\mathrm{Lö}$ & $\mathrm{Ol}+\mathrm{Klp}+\mathrm{Hb}+\mathrm{Lö}+\mathrm{PI}$ \\
\hline & $\mathrm{Ol}+\mathrm{Klp}+\mathrm{Hb}+\mathrm{Ne}+\mathrm{Lö}$ & $\mathrm{Ol}+\mathrm{Klp}+\mathrm{Hb}+\mathrm{Pl}+\mathrm{Lö} \pm \mathrm{Ne}$ \\
\hline
\end{tabular}


gibi koyu renkli minerallerin mikrokristalleri de bulunmaktadır. Matriks kriptokristalin amfibol ve plajiyoklaz mikrolitleri, az miktarda opak mineral ve kahverengi volkanik cam ile temsil edilmektedir.

Klinopiroksenler, kayaçlarda yüzde hacim olarak en çok rastlanan fenokristaldir. Genellikle özșekilli olup, taze ve zonlu dokuya sahiptirler (Șekil 7a). Bazen renksiz, bazen de soluk yeșil renklerde olan klinopiroksen fenokristalleri, temiz ve düzgün kenarlı, kırılmıș ve yuvarlaklașmıș, zonlu dokulu, kemirilmiș, cam kapanımlı, relikt (kalıntı) dokulu, süngerimsi dokulu ve kümülat dokulu olarak bulunmaktadır.

Olivinler, özșekilli olup, çoğunlukla hamurla reaksiyon halde izlenmektedir. Bu nedenle hem yenmiș, hem de yuvarlaklașmıș halde bulunmaktadır (Șekil 7b). Bazı olivinlerde çatlaklar gelișmiștir. Kimi zaman bu çatlaklar boyunca iddingsitleșmeler ve serpantinleșmeler gelișmiștir.

Hornblendler, genellikle kemirilmiș ve opak oksitler tarafından çevrelenmiș (opasitleșmiș) olarak izlenmektedir (Șekil 7c). Bazı kayaç gruplarında tamamen, kimisinde de kısmen opasitleșmeye uğrayan hornblendler sarımsı kahve kuvvetli bir pleokroyizmaya sahiptirler. Özellikle II. Evre'de bu minerallere kümülat halinde rastlanmıștır.

Plajiyoklaz, genellikle hamurda mikrolit olarak yer almaktadır. Fenokristal boyutunda olanlar, polisentetik ikizlenme göstermekte ve genellikle tozlu zon kușakları içermektedirler (Șekil 7d).

Nefelin, genellikle prizmatik yapıya sahip olup, kayaçlarda nadir olarak gözlenmektedir. Bazı nefelinlerin de olivinlerde olduğu gibi, kemirildiği ve yuvarlaklaștığı da izlenebilmiștir.

Lösit, kayaçlarda fenokristal ve hamur içerisinde mikrolit olarak bulunmaktadır. Lösitler, genellikle agrega halinde olup, oksit ve klinopiroksen kapanımları içermektedir.

Opak mineraller hamurda bulunmaktadır. Genellikle özșekilli olup, bazen yuvarlağımsı șekillere sahiptirler. Hamurda serbest halde bulunabildiği gibi bazen diğer mineraller içerisinde kapanım olarak da izlenmektedir.
Hamur, çoğunlukla intersertal doku gösteren mikrolitlerden olușmaktadır. Bazı kayaçlarda cam oranı, mikrolit oranından fazladır. Rengi, soluk kahve renklerden koyu kahve ve siyah renklere kadar değișmektedir. B-II ve B-IIl'e ait bazaltlar gaz boșluklarınca zengindir.

Kula volkanizması silise doygun olmayan lav ve piroklastiklerden olușmaktadır. Kula volkanizmasına ait örnekler TAS (toplam alkali: \% $\mathrm{Na}_{2} \mathrm{O}+\mathrm{K}_{2} \mathrm{O}$ ve silis: \% $\mathrm{SiO}_{2}$ ) diyagramına yerleștirildiğinde (Șekil 8), I ve II. Evre bazaltlarının özellikle bazanit alanında, III. Evre bazaltlarının ise fonotefrit alanında toplandıkları görülmektedir (Alıcı vd., 2002; Șen, 2002). Lavların $\mathrm{SiO}_{2}$ içerikleri \%43 - \%49 arasında ve toplam alkali $\left(\mathrm{Na}_{2} \mathrm{O}+\mathrm{K}_{2} \mathrm{O}\right)$ içerikleri \% 6 - \%9.5 arasında değișmektedir. Tüm örnekler, Miyashiro (1978) Alkali-Kalkalkali kayaç ayııım sınıflamasına göre alkali karakter göstermektedir. I. Evreden III. Evreye doğru gidildikçe kayaçların alkali içeriğinde artıș gözlenmektedir.

Kula volkanik ürünlerinin, okyanus ortası sırtı bazaltlarına benzer özellikler tașıdığı, manto yükselimine bağlı olarak litosferin incelmesi ile birlikte gelișen basınç ferahlaması sonucu astenosferin kısmi ergimesinden türediği ileri sürülmektedir (Yılmaz, 1989, 1990; Güleç, 1991; Seyitoğlu, 1997b; Aldanmaz vd., 2000; Tokçaer vd., 2005; Dilek ve Altunkaynak, 2009 ve 2010; Karaoğlu vd., 2010; Ersoy vd., 2010, 2012). Kula volkanizması iz element ve izotop bileșimlerine göre ise, alt kıtasal litosfer ve astenosferik manto olmak üzere iki farklı kaynaktan fraksiyone olmuș eriyik karıșımlarından türedikleri ve önemli bir kabuksal kirlenmeye uğramadıkları ortaya konulmuștur (Güleç, 1991; Alıcı vd., 2002; Grützner vd., 2013).

\section{PIROKLASTIK ÜRÜNLERIN HACIMSEL HESAPLAMALARI}

Kula bölgesindeki kesik koni morfolojisine sahip tam olarak 64 cüruf konisinin, hemen hemen kesik koni görüntüsü vermeyen 16 küçük koninin, 1 maar, 4 tüf halkasının ve bu monojenetik volkanlardan etrafa yayılan piroklastik çökellerin hacimsel hesaplamaları yapılmıștır. 

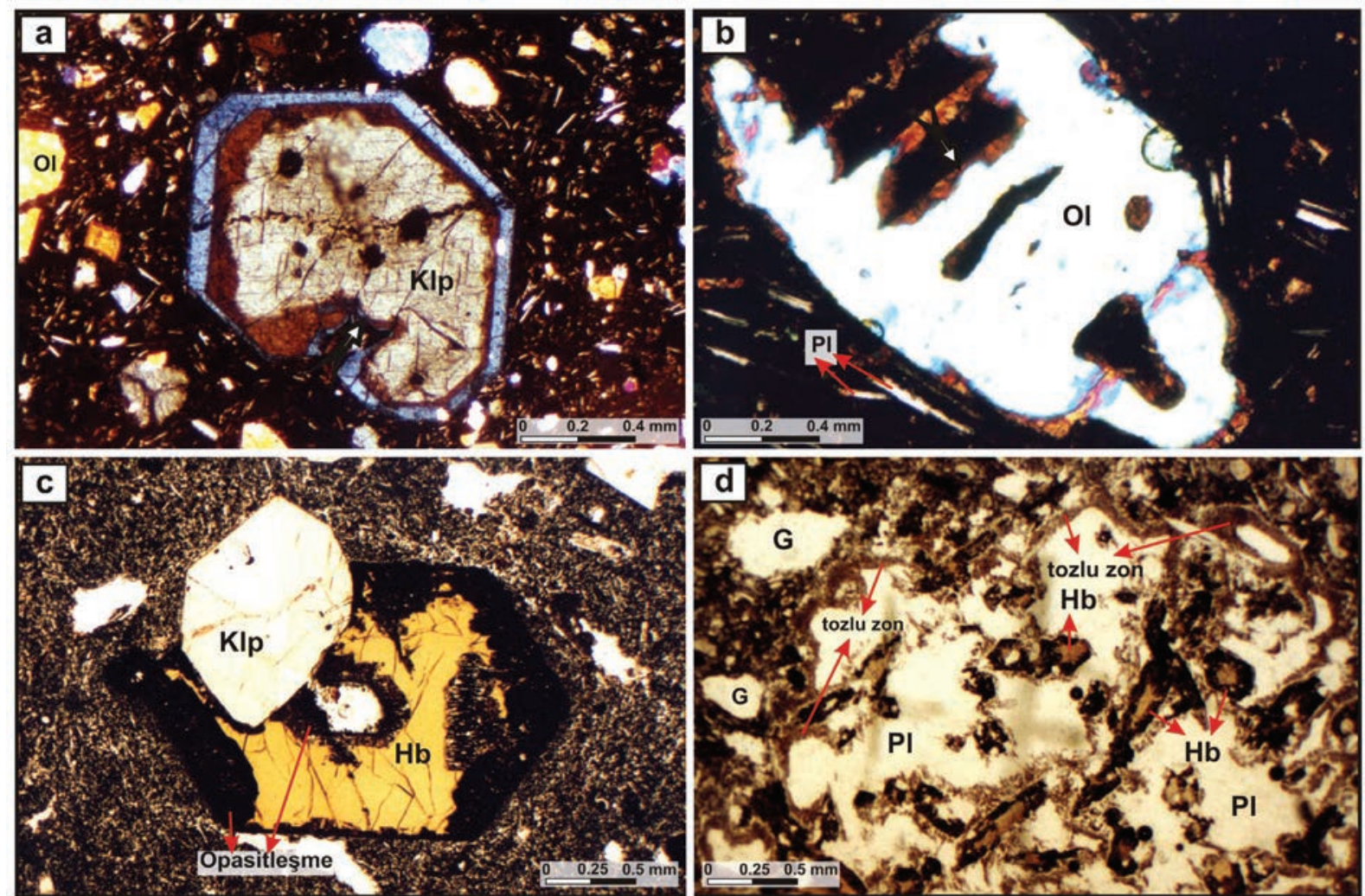

Șekil 7. Kula lavlarına ait mikro-fotoğraf görüntüleri (KIp: klinopiroksen, OI: olivin, Hb: hornblend, G: gözenek, PI: plajiyoklaz a) Zonlu doku gösteren klinopiroksen minerali, beyaz ok ile gösterilen kısımdan itibaren kemirilmiștir, II. Nikol, B-I, b) Kemirilmiș (iskeleti görülebilen) olivin minerali, II. Nikol, B-II, c) Kenar ve iç kısmından opasitleșmiș özșekilli hornblend minerali, I. Nikol, B-Il ve d) Plajiyoklaz mineralleri. Kenarlarından itibaren cam kapanımları (tozlu zon) içermektedir. Kısmen opasitleșmiș hornblend mineralleri kapanım olarak izlenmektedir, I. Nikol, B-II.

Figure 7. Microphotographs of the Kula lavas (KIp: clinopyroxene, Ol: olivine, Hb: hornblende, G: vesicle, Pl: plagioclase). a) Zoned clinopyroxene, it has embayed texture which is shown by white arrow, plane polarized, $B-I$, b) Embayed skeletal olivine, cross polarized, B-II, c) Euhedral hornblende mineral opacitizated from rim and core, plane polarized, B-Il and d) Plagioclase minerals with glass inclusions as dusty zone in the rim, plane polarized, B-II.

\section{Metodoloji}

Patlamalı olarak gerçekleșen monojenetik püskürmelere ait piroklastik ürünler kendi volkanik yapısını (koni veya maar) olușturdukları gibi, malzelerinin önemli bir miktarını da çevreye yaydıkları çok iyi bilinmektedir. O nedenle, yapılan hacimsel hesaplamalar hem volkanik yapıyı hem de etrafa yayılan tüm piroklastik ürünleri kapsamaktadır.

\section{a) Cüruf konileri}

Cüruf konilerinin boyutları ve hacimsel ilișkileri Porter (1972), Wood (1980) ve Carn (2000) tarafından detaylı olarak çalıșılmıș ve bazı parametreler geliștirilmiștir (Șekil 9). Carn, (2000) yapılan hesaplamalarda genç cüruf konilerine ait istatistiki verileri kullanmıștır.

Porter, (1972) cüruf konilerinin boyutları arasındaki ilișkiyi așağıdaki eșitliklerle ortaya koymuștur:

$\mathrm{Hco}=0,18 \times$ Wco

$\mathrm{Wcr}=0,40 \times \mathrm{Wco}$

Bu eșitliklerde, Wcr, krater çapını;

Wco, koni taban çapını; Hco, koni yüksekliğini tanımlamaktadır. 


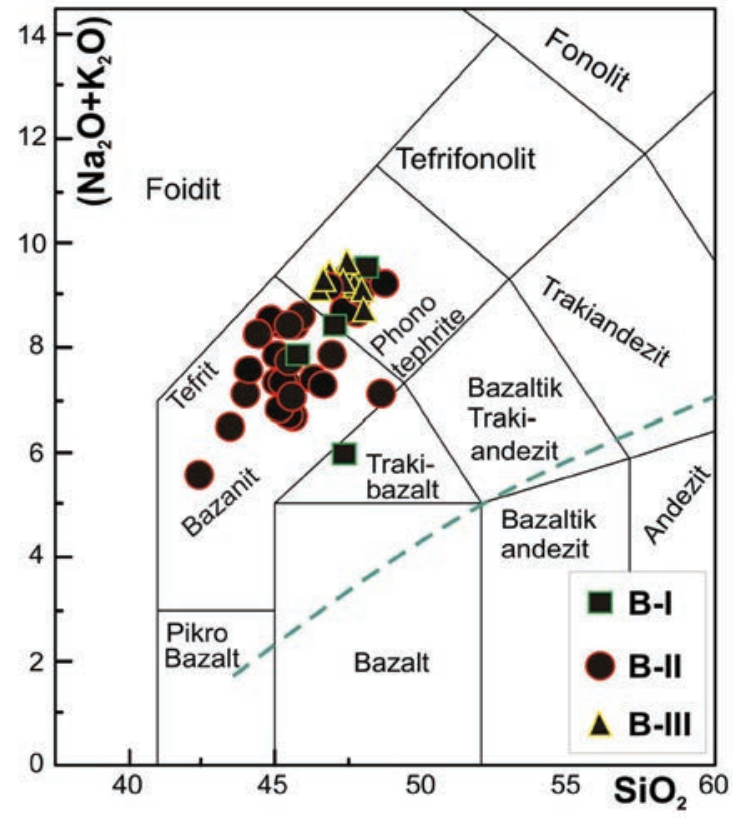

Șekil 8. Kula lavlarının Toplam alkali-silis diyagramı (Le Bas vd., 1986) üzerinde gösterimi (Șen, 2002; Alıcı vd., 2002).

Figure 8.Total alkali-silica diagram (Le Bas et al., 1986) of Kula lavas (Șen, 2002; Alıcı et al., 2002).

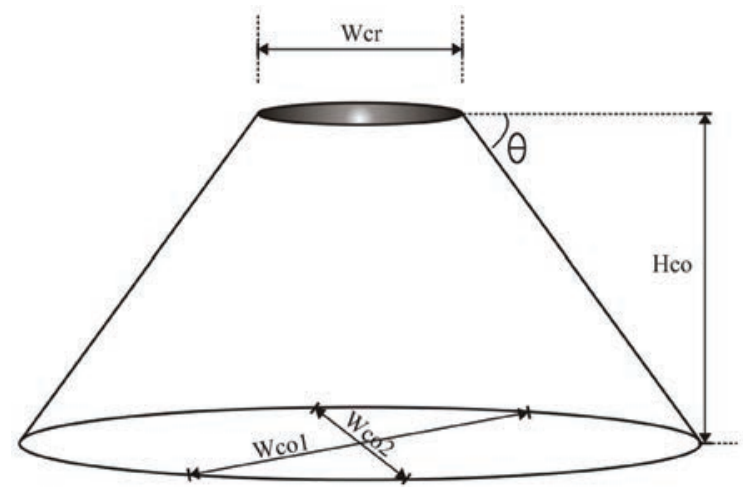

Șekil 9. Tipik bir cüruf konisinin șematik olarak gösterimi. Wcr: krater çapı, Wco1 ve Wco2: koni uzun ve kısa taban çapı, Hco: koni yüksekliği, $\theta$ : Yamaç eğimi (Wood, 1980; Carn, 2000).

Figure 9. Schematic diagram of a typical cinder cone. Wcr: crater diameter, Wco1 and Wco2: long and short basal diameter of cone, Hco: cone height, $\theta$ : cone slop angle (Wood, 1980; Carn, 2000).
Yapılan hesaplamalar için sırasıyla;

1). Koni hacmi $\left(V_{C}\right)$ için, simetrik, kesik koni hacim formülü kulanılmıștır;

$\mathrm{Vc}=(\pi \mathrm{Hco}) / 12\left(\left(\mathrm{Wcr}^{2}+\mathrm{Wcr} \times \mathrm{Wco}+\mathrm{Wco}^{2}\right)\right)$

(3) (Hasenaka ve Carmicheal, 1985)

Krater olmadığı durumlarda koninin üzerindeki topografik düzlem çap olarak kullanılmıștır. Karnıyarık konilerde ise karnıyarığı çevreleyen sırtların arasındaki mesafe krater çapı olarak kabul edilmiștir.

2). Krater çapından faydanılarak püskürüp giden piroklastiklerin hacmi $\left(\mathrm{V}_{\mathrm{E}}\right)$ hesaplanmıștır;

$\mathrm{V}_{\mathrm{E}}^{0.42}=0,11 /$ Wcr (Sato ve Taniguchi, 1997) (4)

3). Buradan yola çıkılarak toplam hacim $\left(V_{T}\right)$ bulunmuștur;

$\mathrm{V}_{\mathrm{T}}=\mathrm{V}_{\mathrm{C}}+\mathrm{V}_{\mathrm{E}}(\mathrm{YKE})$

\section{b) Maarlar}

Parametrelerin saptanmasında arazi gözlemlerinin yanı sıra topografik haritalar ve hava fotoğraflarından yararlanılmıștır. Maarların çeșitli morfolojik parametreleri Șekil 10'da verilmiștir. Maar olușumu sırasında ortaya çıkan malzemelerin hacimsel hesaplamaları așağıdaki eșitliklerden faydanılarak yapılmıștır:

- $\mathrm{V}_{\mathrm{M}}$ : Krater tabanı ile yer arasında kalan kısmın hacmi (Silindirin hacim formülü kullanılmıștır; Carn, 2000)

$\mathrm{V}_{\mathrm{M}}=\pi(\mathrm{Dv} / 2)^{2} \mathrm{dv}$

Burada, Dv, krater taban çapı (m);Dv, krater tabanı ile yer seviyesi arasındaki yükseklik farkı (m)

Çukurada Maarında taban yüksekliği ile dıș topoğrafik yükseklik arasındaki farklılık nedeniyle bu hesaplama mümkünken tüf halkalarının topoğrafik özelliği nedeniyle mümkün değildir. Carn (2000)'ın yaptığı gibi, tüf halkaları için Vm hesabı yapııırken dv (krater tabanı ile yeryüzü arasındaki yükseklik farkı) miktarı $15 \mathrm{~m}$ alınmıștır.

- $\mathrm{V}_{\mathrm{E}}$ : Toplam püsküren malzeme hacmi (Sato ve Taniguchi, 1997)

$V_{E}=(D o / 0,97)^{100 / 36}$ 


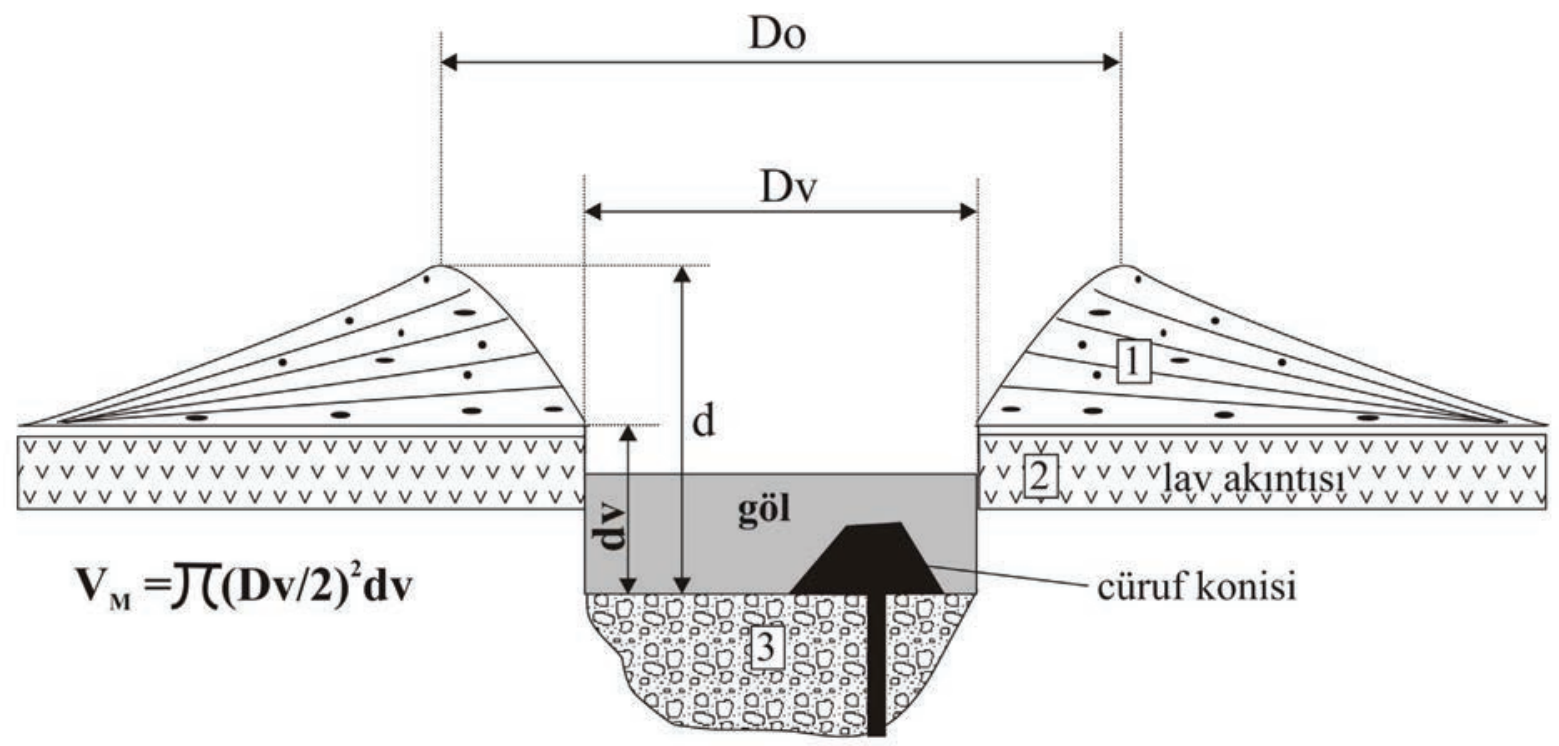

Șekil 10. Tipik bir maarın șematik gösterimi. Do: ortalama krater çapı; d: toplam krater derinliği; Dv: yeraltı krater çapı; dv: yeraltıaltı krater derinliği ve VM: maar olușumu süresince açığa çıkan litiklerin tahmin edilen hacmini temsil etmektedir. Kare içerisinde gösterilen numaralardan (1): Maar çökellerini (taban yayılımı ürünleri); (2): maar öncesi ürünleri ve (3): maar diyatrem / patlama breșlerini ifade etmektedir (Carn, 2000).

Figure 10. Schematic diagram of a typical maar. Do: average crater diameter, d: total crater depth, Dv: sub-surface crater diameter, dv: sub-surface crater depth, VM: the estimated volume of lithic material excavated during the maar forming eruption, (1): base surge deposits, (2): pre-explosion rocks and (3): maar diatreme / explosion breccia (Carn, 2000).

Do, Krater ortalama çapı

- $V_{j}$ : Püsküren jüvenil magma miktarı (Carn, 2000)

$\mathrm{V}_{\mathrm{J}}=\mathrm{V}_{\mathrm{E}}(\mathrm{YKE})-\mathrm{V}_{\mathrm{M}}$

$V_{E}(Y K E) ;$ Püsküren tüm malzemenin Yoğun Kayaç Eșitliği

\section{Bulgular}

\section{Cüruf konileri}

Krater derinlikleri $1 \mathrm{~m}$ ile $50 \mathrm{~m}$ arasında değișmektedir. Kula bölgesindeki mevcut kraterlerin büyük çoğunluğu eșyükseklik eğrileri aralığından az olduğu için krater derinliği tanımlayıcı bir ölçüt olarak kullanılmamıștır. Konilerin morfolojik özellikleri kullanılarak kraterin yașlı veya genç olduğu hakkında yaklașımlarda bulunulmuștur. Așınma durumu göz önüne alındığında, koni taban çapı / koni yüksekliği oranının (Wco/Hco) düșük çıktığı, buna karșın yüksek yamaç eğimlerinin $(\theta)$, ve çok iyi tanımlanmıș koni kraterlerin varlığının nispeten genç konilerde yaygın olduğu görülmektedir (Carn, 2000). Konilere ait çeșitli parametreler ve hacimsel hesaplamalar Çizelge 2'de verilmiștir.

Hesaplama yapilırken dikkat edilmesi gereken nokta, koniden püsküren piroklastiklerin YKE değerlerinin toplama dahil edilmesidir. Bunun için cüruf tanelerinin ortalama yoğunluğu hesaplanmıș ve $1,8 \mathrm{gr} / \mathrm{cm}^{3}$ olarak bulunmuștur. YKE değeri, cüruf yoğunluğunun $\left(1,8 \mathrm{gr} / \mathrm{cm}^{3}\right)$ bazalt yoğunluğuna $\left(2,7 \mathrm{gr} / \mathrm{cm}^{3}\right)$ oranının verdiği katsayı ile $V_{E}$ çarpılarak bulunmuștur. YKE doğruluk derecesi en fazla genç koniler için geçerli olmaktadır. Yașlı konilerdeki așınmalar, faaliyetle beraber gerçekleșen lav akıntıları ve krater yapıları nedeniyle hesaplanan değerler minimum değerde olacaktır (Carn, 2000). Bu kayıp Wood (1980) tarafından \%20 olarak belirlenmiștir.

Ortalama koni taban çapı $553 \mathrm{~m}$, medyan değeri ise $556 \mathrm{~m}$ olarak bulunmuștur. Wood, (1980) yaptığı çalıșmada ise cüruf konilerinin 


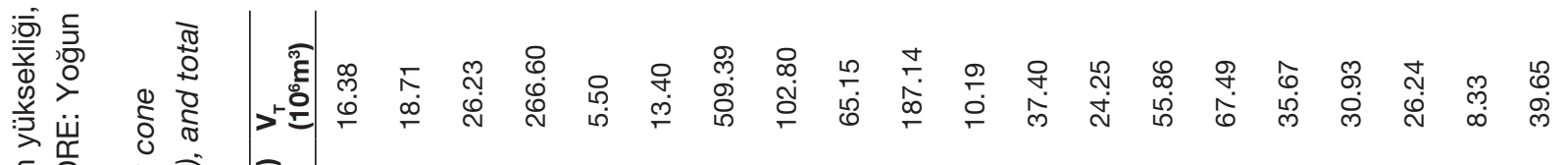

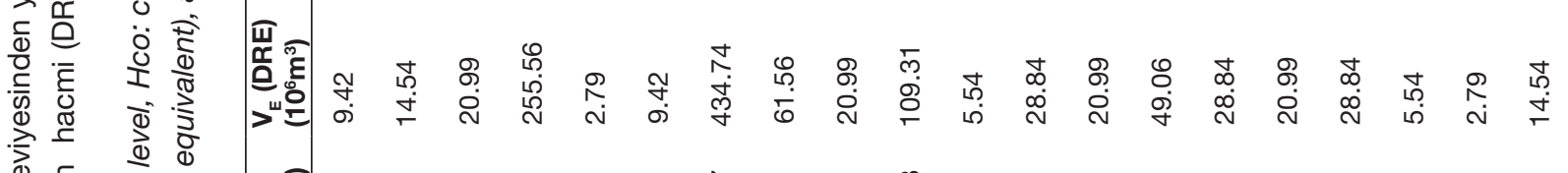

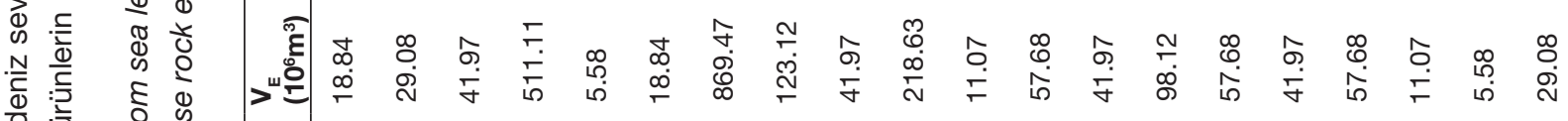

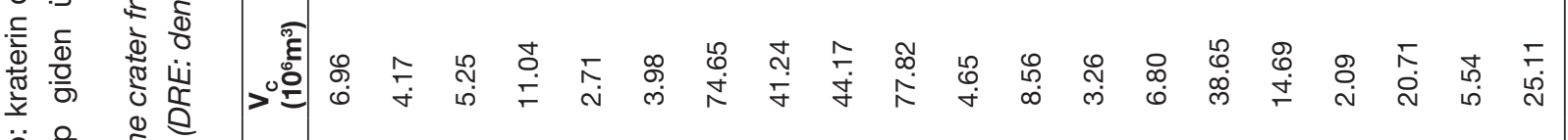
立落

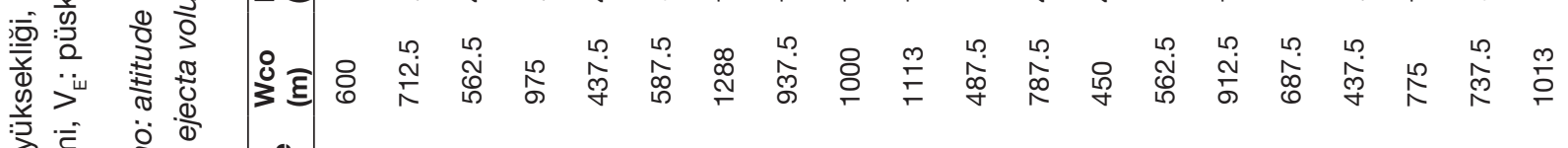

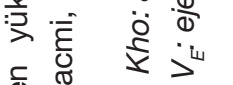

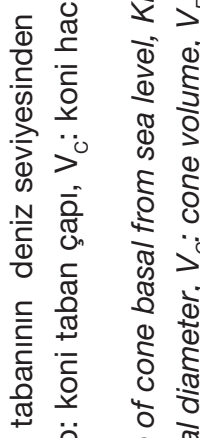

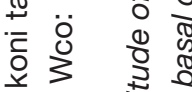

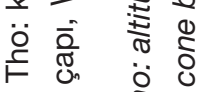
एँ ऐ. ऐ

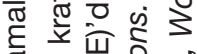

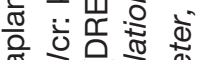
क्ष \浐>论 d 竞

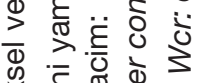

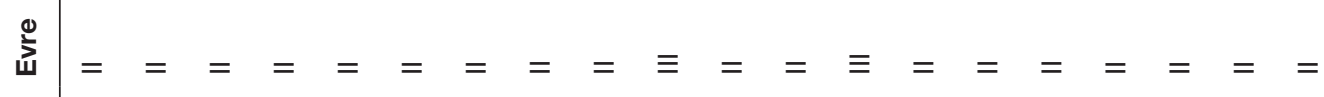

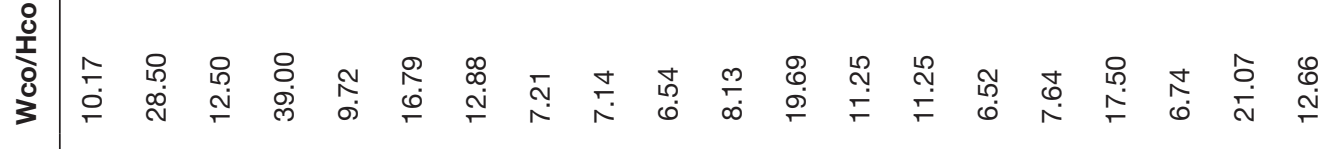

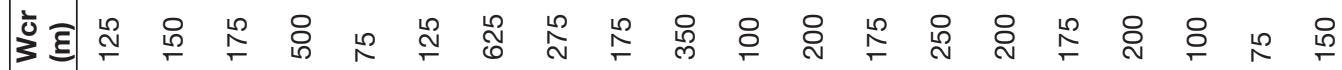

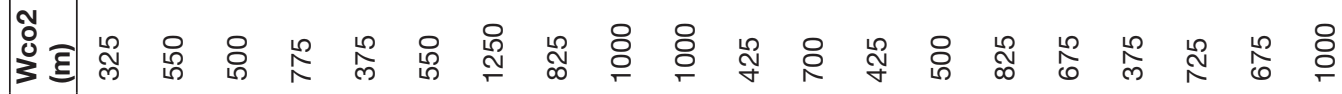

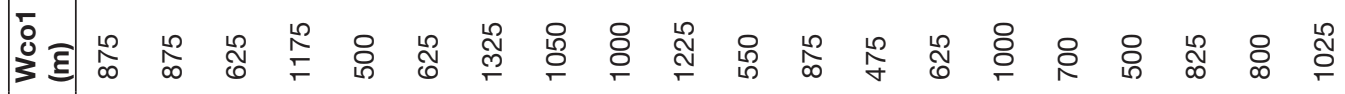

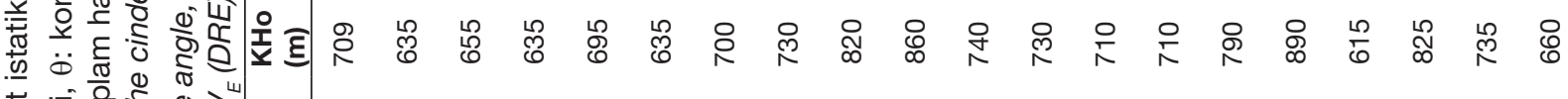

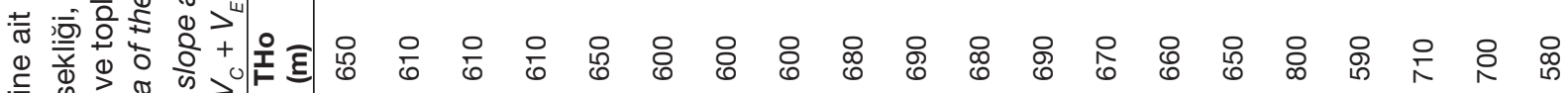

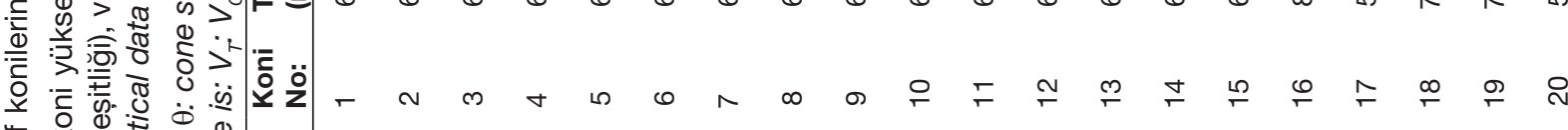

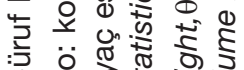
ن.

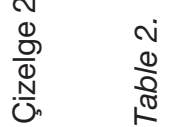

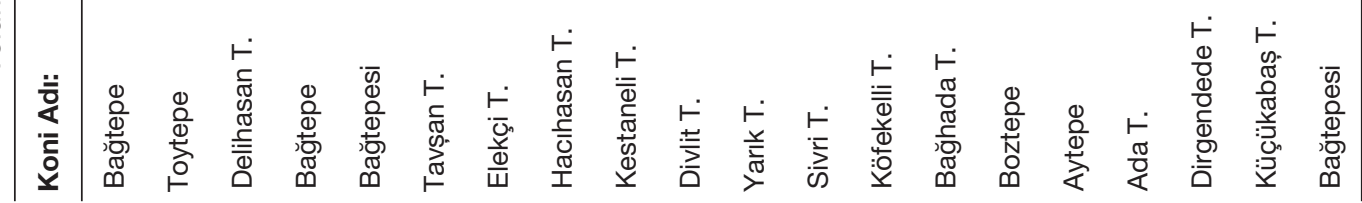




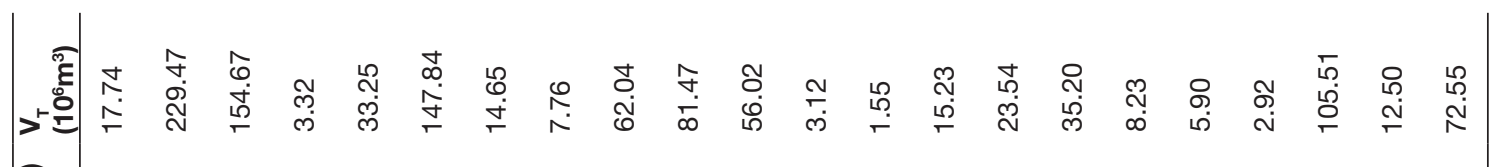

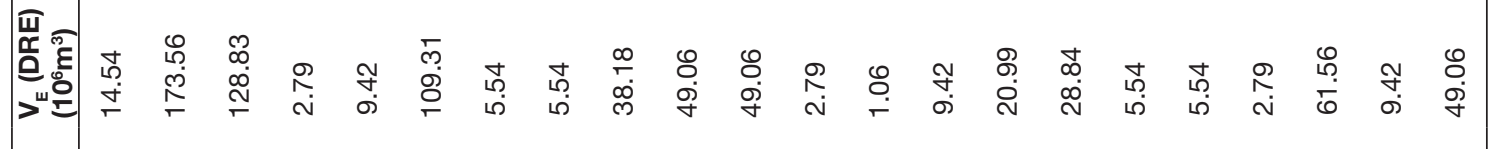
$>$ > $>>$ >

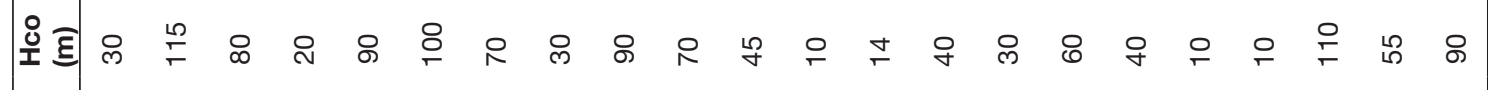

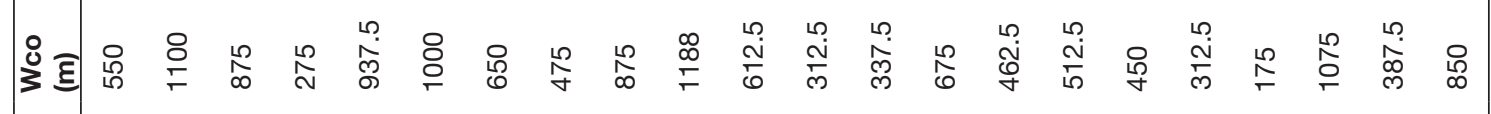

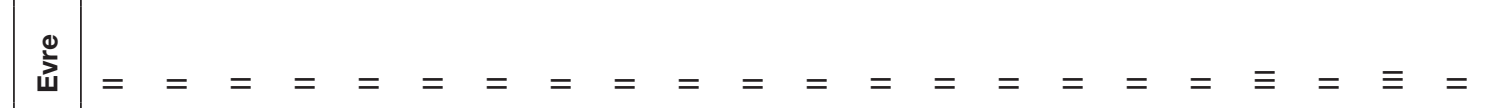

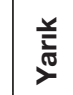

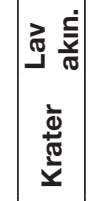
究

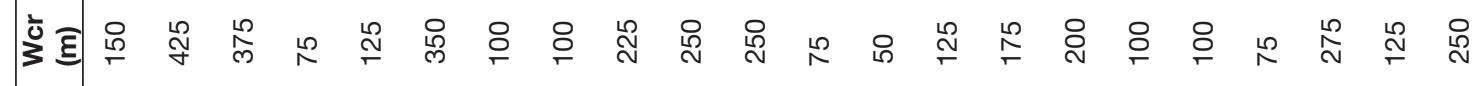

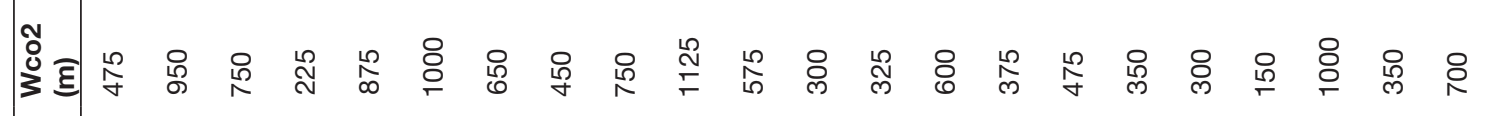

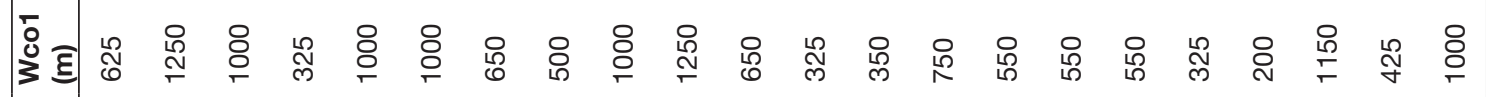
§)

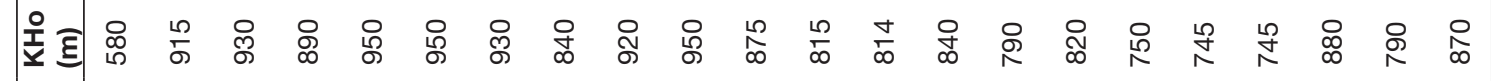
疋梟唝 ㅎํํ. צ̊ำ

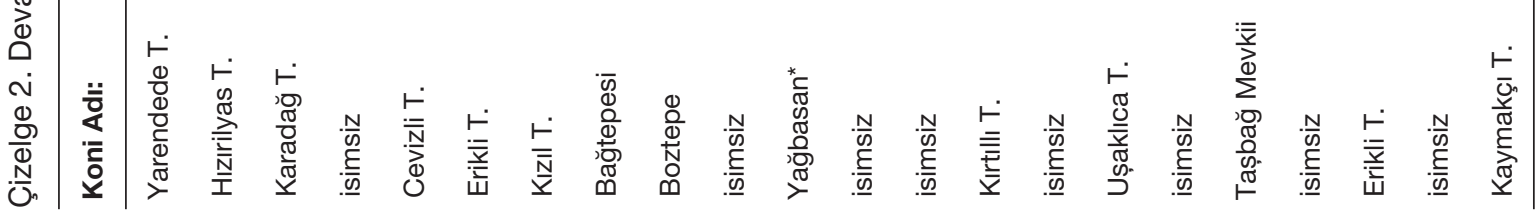




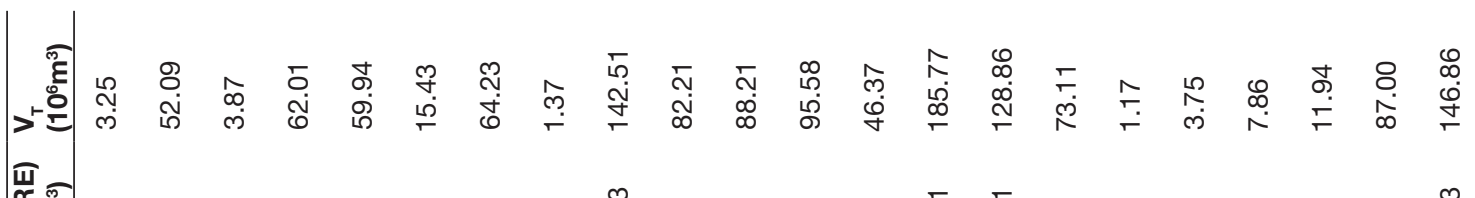

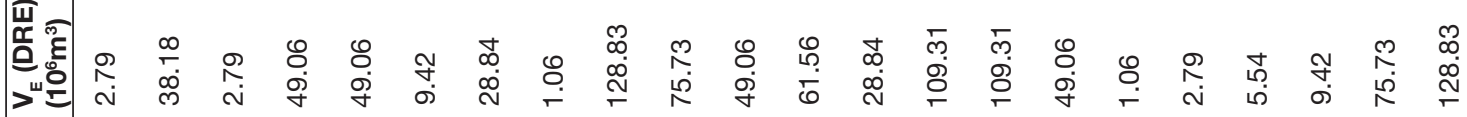

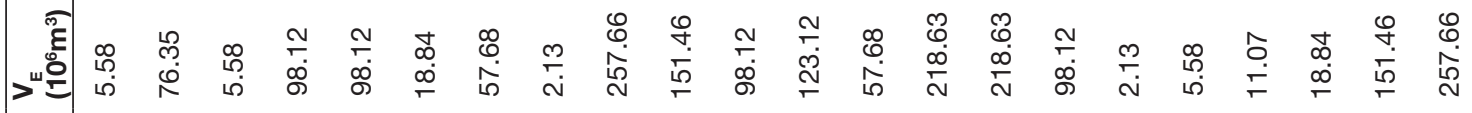

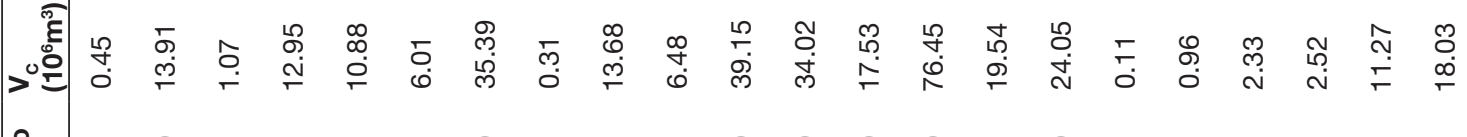

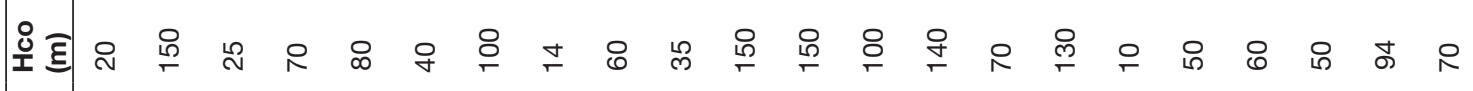
j)

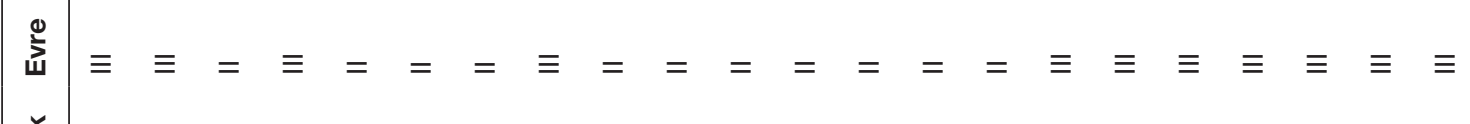

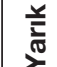

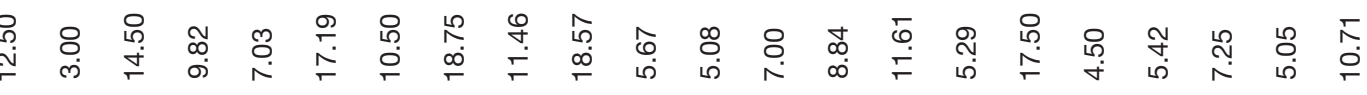

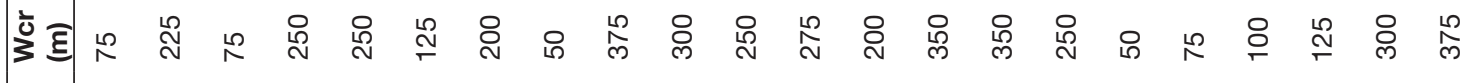

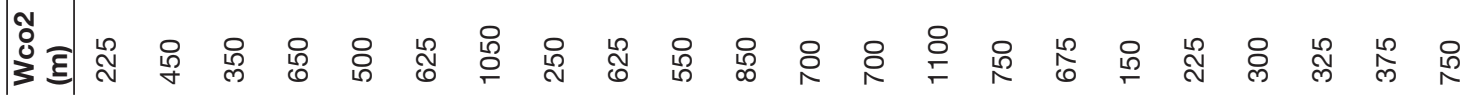

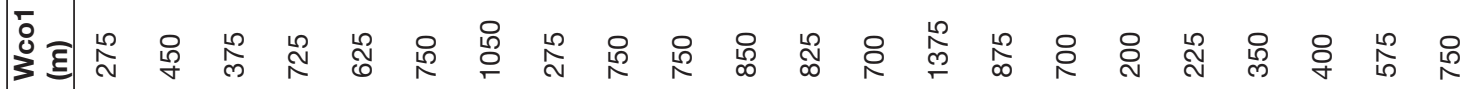

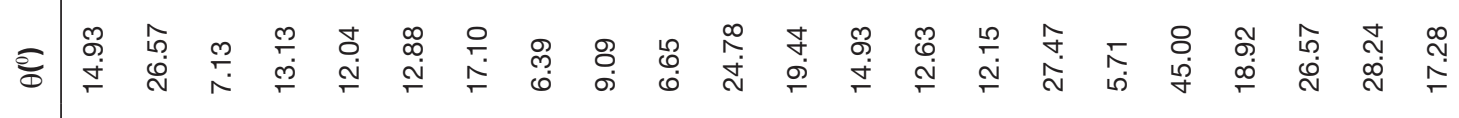
오틔

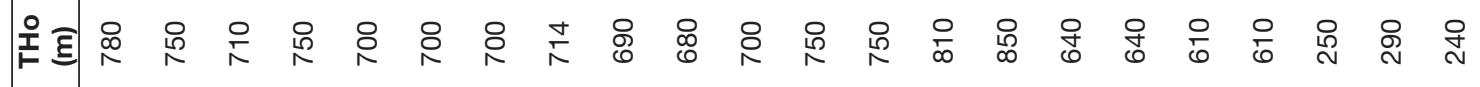

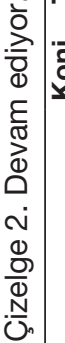

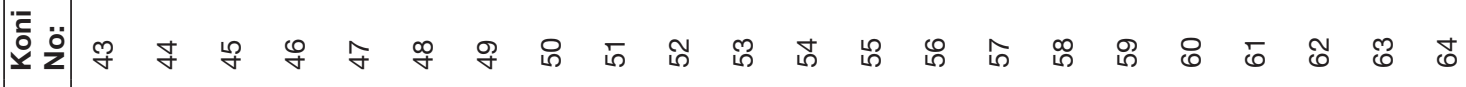

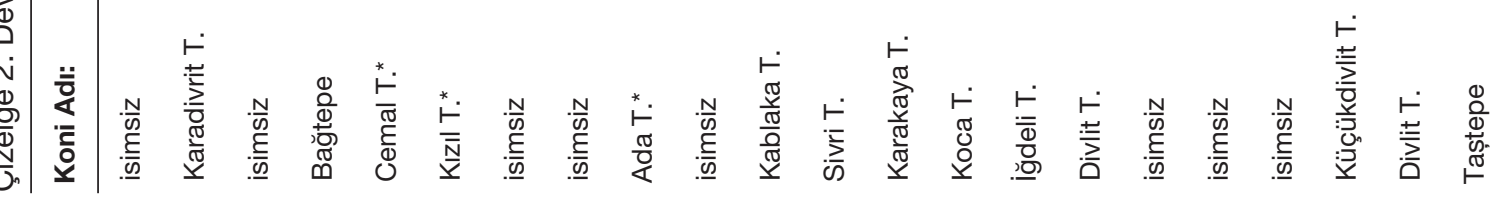




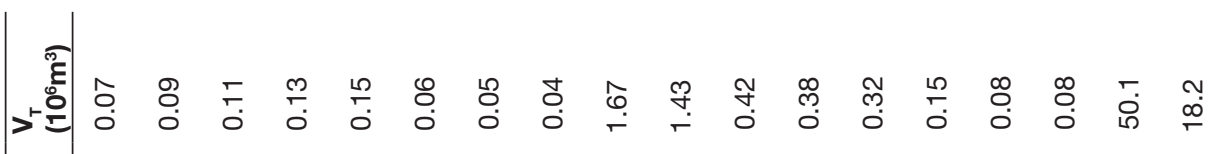

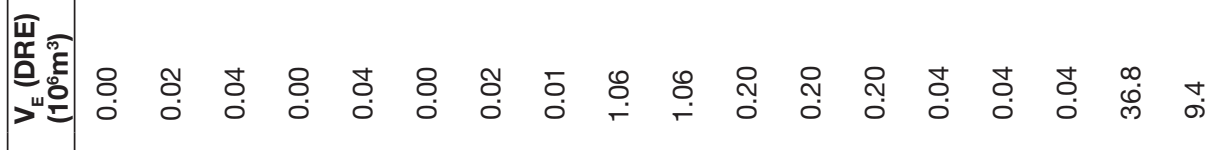

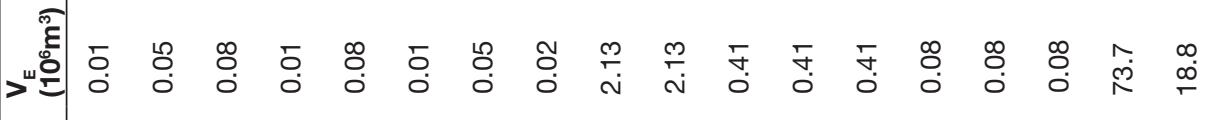
>

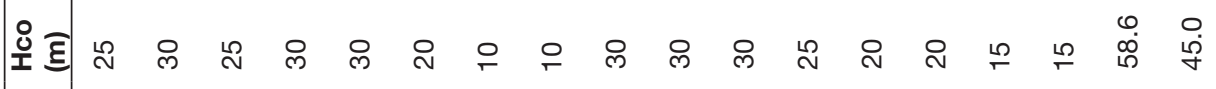

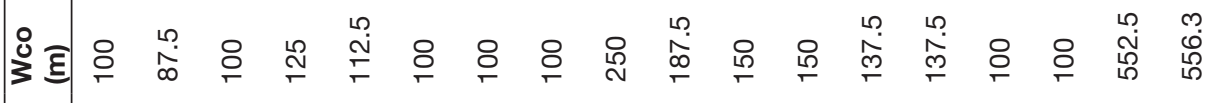

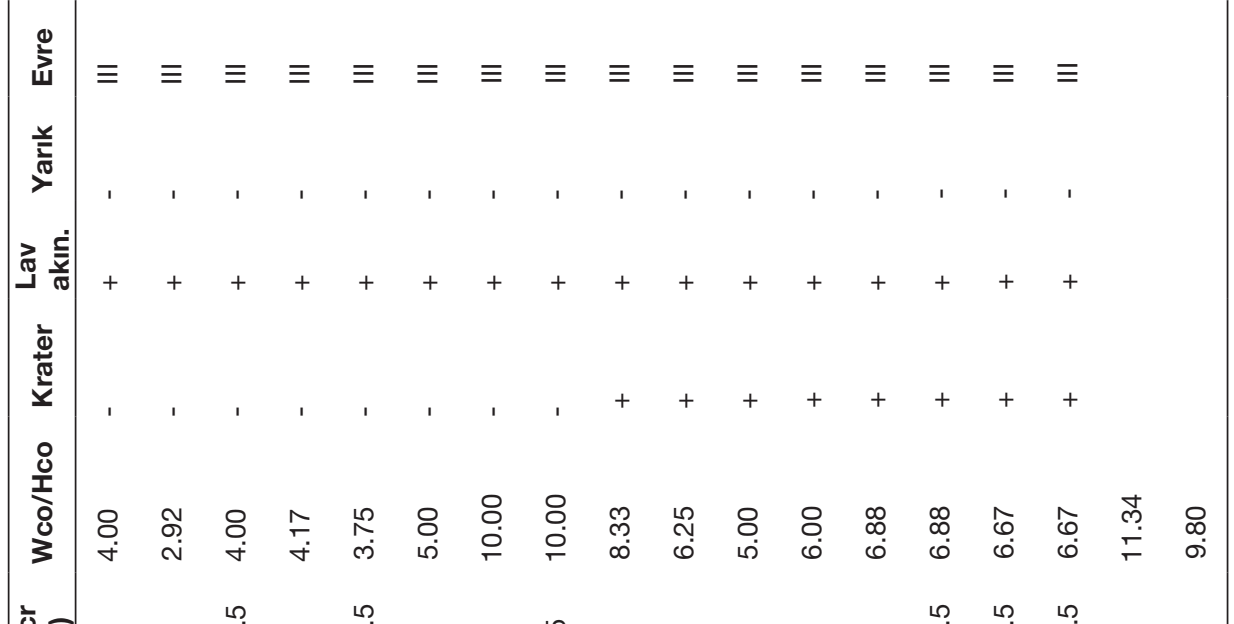

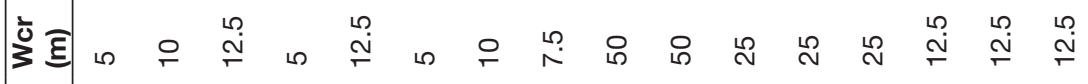

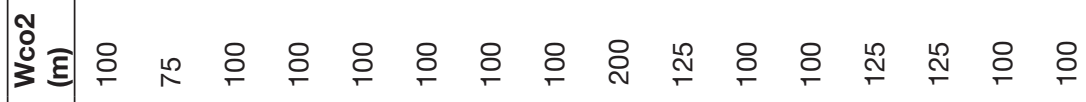

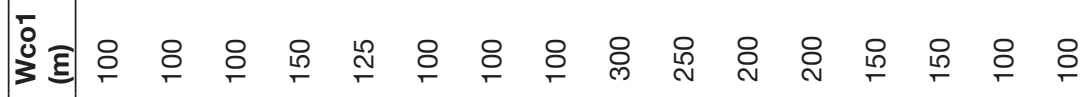

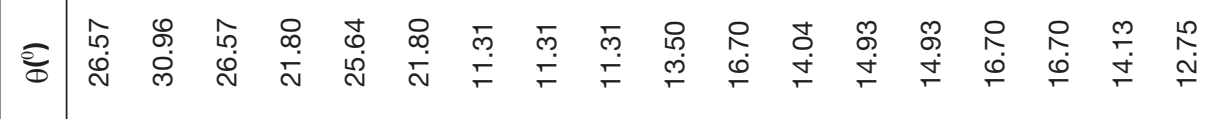

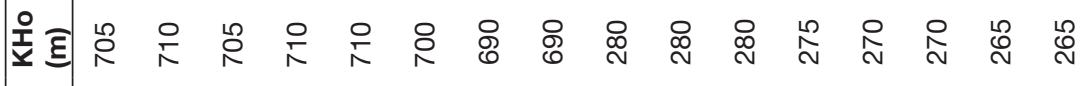
웉ㅌ

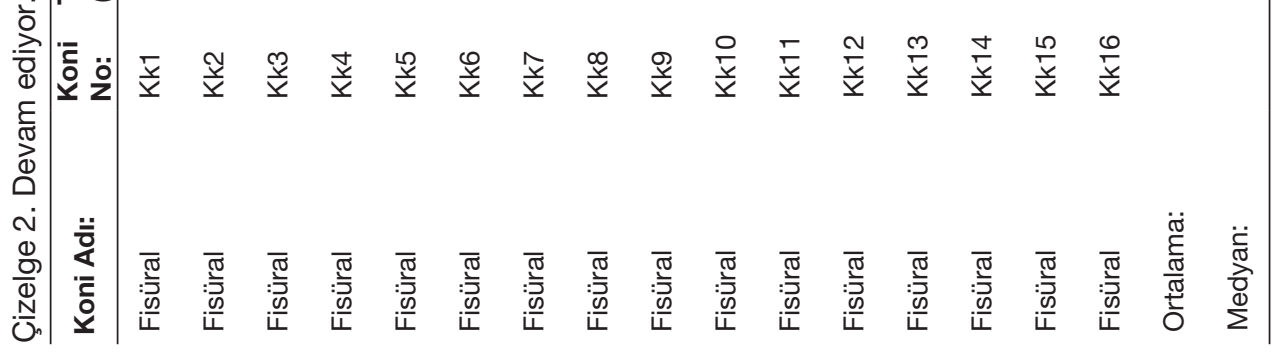


küresel ortalama taban çapı değerini $900 \mathrm{~m}$ ve medyan değerini 800 m bulmuștur. Kula bölgesindeki cüruf konilerine ait taban çaplarındaki değerler evrensel değerlerin altında çıkmıștır. Ayrıca, ortalama ve medyan değerleri arasında $3 \mathrm{~m}$ gibi inmal edilecek ölçüde bir fark bulunmaktadır. İnmal edilebilecek bu küçük fark KVA'daki cüruf konilerinin yaklașık aynı fiziksel özelliklere sahip olduğunu göstermektedir. Çünkü, bu çalıșmada ortalama yerine medyan kullanımasının amacı konilerin fiziksel yapısındaki heterojenliğin sonuca yansıtacağı etkiyi azaltmak ve doğruya çok daha fazla yaklașmaktır. Nitekim, konilerin așınma oranlarını sadece zaman belirlememektedir. Konilerin fiziko-morfolojik içyapısı en az zaman kadar önemli olmaktadır. Bașka bir deyișle, yașlı olduğu halde son derece dayanıklı yapıya sahip olan bir koni uzun süre varlığını devam ettirecek, diğerleri așınırken kendisi erozyondan en az etkilenen konumda olacaktır. Bu durumda, konilerin așınmasında kullanılan ortalama değerlerde de önemli sayılabilecek sapmalar meydana gelecek ve doğrudan uzaklașılmıș olacaktır.

Kula volkanizmasına ait sadece konilerin hacim toplamı $\left(V_{c}\right) 1,063 \mathrm{~km}^{3}$ ve konilere ek olarak püsküren piroklastik ürünlerin hacim toplamı $\left(V_{\mathrm{E}}\right) 5,895 \mathrm{~km}^{3}\left(2,947 \mathrm{~km}^{3}\right.$ YKE) olarak hesaplanmıștır. Tüm değerlerin toplamı ise $\left(\mathrm{V}_{\mathrm{T}}=\mathrm{V}_{\mathrm{C}}+\mathrm{V}_{\mathrm{E}(\mathrm{YKE})}\right)$ $4,01 \mathrm{~km}^{3}$ olarak tespit edilmiștir. Ancak, Carn (2000) cüruf konilerinin hacmini hesaplarken kesik konileri tüm katı olarak değerlendirmiștir. Bu durumda koniyi olușturan ürünler arasındaki boșluğu ve aynı zamanda cüruf tanelerinin gözenekliliğini de inmal etmiștir. O nedenle bu çaIıșmada hesaplamalar yapılırken konilerin yığın yoğunluğu da ele alınmıștır.

Cüruf konilerinin yığın yoğunluğunu $0,8 \mathrm{gr} / \mathrm{cm}^{3}$ olarak kabul ettiğimiz ve yoğun kayaç eșitliğine $\left(2,8 \mathrm{gr} / \mathrm{cm}^{3}\right)$ oranladığımızda tüm konilerin toplam $\mathrm{V}_{\mathrm{C}}$ değeri:

$\mathrm{V}_{\mathrm{CT}}(\mathrm{YKE})=\mathrm{V}_{\mathrm{CT}} \times(0,8 / 2,8)=1,063 \times(0,8 / 2,8)=$ $0,304 \mathrm{~km}^{3}$ olarak yeniden hesaplanması gerekmektedir. Bu düzeltmeden sonra Kula'daki cüruf konilerinin ve onların cüruf geri-düșme ürünlerinin YKE miktarı $\left(\mathrm{V}_{\mathrm{T}}=\mathrm{V}_{\mathrm{CT}}(\mathrm{YKE})+\mathrm{V}_{\mathrm{E}}(\mathrm{YKE})\right)$, $3,25 \mathrm{~km}^{3}$ olarak bulunmuștur.

\section{Maarlar}

Maarlarla ilgili yapılan hacimsel hesaplamalar Çizelge 3'te verilmiștir. Burada, dikkat edilmesi gereken en önemli parametre, püsküren malzemenin depolandıktan sonra sahip olduğu yığın yoğunluğudur. Taban yayılımı ürünlerindeki kül ve litik oranı cüruf konilerdeki piroklastik ürünlere göre daha fazla olduğu saptanmıștır. Bu nedenle, Aramaki vd.'nin (1986) maar ürünleri için buldukları ortalama 1,3 gr/cm ${ }^{3}$ lük yığın yoğunluğuk değerinin curuf konilerinkinden daha fazla çıkması normaldir. Jüvenil kırıntının yoğunluğu cüruf konilerinde olduğu gibi yine $1,8 \mathrm{gr} / \mathrm{cm}^{3}$ olarak alınmıștır. Bu değerler katı bazalt kayacın yoğunluğuna oranlanınca $0,46\left(V_{E}\right.$ için) ve 0,64 $\left(V_{J}\right.$ için) sonuçları çıkmıștır. Bu șekilde püsküren malzemenin yoğun kayaç eșitliğ $\mathrm{V}_{\mathrm{E}(\mathrm{YKE})} ; \mathrm{V}_{\mathrm{E}}$ değerinin 0,46 ile çarpılmasıyla elde edilmiștir. $V_{J}$ değeri, zaten yoğun kayaç eșitliği șeklindedir. Püsküren jüvenil magmanın da doğada ne kadar hacim kaplayacağını öğrenmek için $V_{\jmath}$, 100/64 değeri ile çarpılmıștır (Çizelge 3).

Sonuçlara bakıldığında maar olușturan püskürmeler sırasında ortaya çıkan malzeme miktarı $0,36 \mathrm{~km}^{3}$ (YKE) olarak bulunmuștur. Ortaya çıkan juvenil magma miktarı ise $0,34 \mathrm{~km}^{3}$ (YKE) olarak hesaplanmıștır. Bu değere cüruf konilerinden çıkan toplam tefra değerini de eklediğimizde, Kula'da üretilen toplam piroklastik çökellerin YKE miktarı $\sim 3,6 \mathrm{~km}^{3}$ olarak hesaplanmaktadır.

\section{TARTIȘMA VE SONUÇLAR}

\section{Tektonik Kontrol ve Hızlı Yükselim}

Tektonik gerilme hatları monojenetik volkanların yeryüzündeki dağılımını belirleyebilmektedir (Chadwick ve Dieterich, 1995; Ramos ve Folguera, 2011; Cebriá vd., 2011, Gudmundsson, 2012). Tansiyonel kırıklar, normal faylar ve graben gibi genleșme yapılarıyla beraber bulunan volkanik merkezlerin büyük çoğunluğu ana tektonik hatlara paralellik göstermektedir (Rubin ve Pollard, 1988; Gudmundsson, 2002; Klügel vd., 2005). Bu olay Kula monojenetik volkanlarının diziliminde açıkça görülmektedir. Kula monojenetik volkanlarının bulunduğu alan elipsoyidal 
Çizelge 3. Kula maarlarına ait morfoloji ve istatistiksel bilgiler. Hcr1: Krater sırtının deniz seviyesinden yüksekliği, Hcr2: Krater tabanının deniz seviyesinden yüksekliği, Dmax, Dmin ve Do: kraterin büyük, küçük ve ortalama çapı, Dv: Kraterin taban çapı, d: Toplam krater derinliği, Do/d: Maarınn zaman ve erozyon ile olan ilișkisini incelemek için hesaplanmıștır, Dmax/Dmin: Kraterin șeklini ölçmek için hesaplanmıștır (1=yuvarlak, $>1=e l i p s o y i d a l), V_{\mathrm{M}}$ : krater tabanı ile yer seviyesi arasında kalan kısmın hacmi, $\mathrm{V}_{\mathrm{E}}$ : Kraterden çıkan tüm partiküllerin hacmi ( $D=0.97 \mathrm{~V} 0.36$ : sato ve Taniguchi, 1997. Burada D: Krater çapı, V: Çıkan piroklastiklerin hacmidir), ve $V_{j}$ : Jüvenil magmanın hacmi. $a: d v=15 \mathrm{~m}$; ve $b=40$ m'dir.

Table 3. Morphology of Kula maars and statistical data. Hcr1: altitude of crater summit from sea level, Hcr2: altitude of crater floor from sea level, Dmax, Dmin and Do: maximum, minimum and average crater diameter, respectively, Dv: crater floor diameter, d: total crater depth, Do/d ratio is calculated to sea relationship between time and erosion. Dmax/Dmin ratio is calculated to measure crater shape $(1=$ circular, $>1=$ ellipsoidal), $V_{M}$ : maar volume between the crater floor and the pre-eruption topography, $V_{E}$ : total ejecta volume Kraterden çıkan tüm partiküllerin hacmi ( $D=0.97 V 0.36$ : Sato and Taniguchi, 1997. D: crater diameter, $V$ : volume of pyroclastics), and $V_{j}$ : volume of juvenile magma. $a: d v=15 \mathrm{~m}$ and $b=40 \mathrm{~m}$.

\begin{tabular}{|c|c|c|c|c|c|c|c|c|}
\hline Maar Adı: & $\begin{array}{l}\text { Maar } \\
\text { No: }\end{array}$ & $\begin{array}{l}\text { Hcr1 } \\
(\mathrm{m})\end{array}$ & Hcr2 (m) & $\begin{array}{c}\text { Dmax } \\
(\mathrm{m})\end{array}$ & $\operatorname{Dmin}(\mathrm{m})$ & Do (m) & Dv $(m)$ & $d(m)$ \\
\hline Yağbasan Tepe & M1 & 875 & 810 & 875 & 825 & 850 & 350 & 65 \\
\hline Cemal Tepe & M2 & 713 & 680 & 1125 & 850 & 987.5 & 625 & 33 \\
\hline Kızıl Tepe & M3 & 715 & 695 & 875 & 725 & 800 & 600 & 20 \\
\hline Çukurada & M4 & 720 & 610 & 1000 & 800 & 900 & 375 & 110 \\
\hline Divlit Tepe & M5 & 300 & 260 & 875 & 600 & 737.5 & 325 & 40 \\
\hline Maar Adı: & $\begin{array}{l}\text { Maar } \\
\text { No: }\end{array}$ & Do/d & $\begin{array}{l}\text { Dmax/ } \\
\text { Dmin }\end{array}$ & $\begin{array}{c}V_{M}\left(10^{6}\right. \\
\left.m^{3}\right)\end{array}$ & $\begin{array}{c}V_{E}\left(10^{6}\right. \\
\left.m^{3}\right)\end{array}$ & $\begin{array}{c}V_{E} \text { (DRE) } \\
\left(10^{6} \mathrm{~m}^{3}\right)\end{array}$ & $v_{J}\left(10^{6} m^{3}\right)$ & $\begin{array}{c}V_{\mathrm{J}} \text { (DRE) } \\
\left(10^{6} \mathrm{~m}^{3}\right)\end{array}$ \\
\hline Yağbasan Tepe & M1 & 13.1 & 1.061 & $1.44 \mathrm{a}$ & 149.29 & 68.6717 & 104.58 & 67.229 \\
\hline Cemal Tepe & M2 & 29.9 & 1.324 & $4.6 a$ & 226.41 & 104.151 & 154.86 & 99.551 \\
\hline Kızıl Tepe & M3 & 40 & 1.207 & $4.24 a$ & 126.15 & 58.0286 & 83.673 & 53.79 \\
\hline Çukurada & M4 & 8.18 & 1.25 & $4.42 \mathrm{~b}$ & 174.97 & 80.4882 & 118.34 & 76.073 \\
\hline \multirow[t]{2}{*}{ Divlit Tepe } & M5 & 18.4 & 1.458 & $1.24 \mathrm{a}$ & 100.64 & 46.2923 & 70.076 & 45.049 \\
\hline & & & Toplam & 15.94 & 777.459 & 357.6313 & 531.519 & 341.691 \\
\hline
\end{tabular}

olup, iki farklı yönde uzanım göstermektedir (Șekil 2). Bu yönler KD-GB (Selendi baseninin uzanımı) ve KB-GD (Gediz Grabeninin uzanımı) șeklinde gelișmektedir. Monojenetik yapıların bazılarının ana doğrultulardan saparak farklı doğrultulardaki kırık zonlarını takip ettiği düșünülmektedir (Șekil 2). Yer içindeki magmanın diapirik yükselimi yüzeyde değișik uzanımlı çatlak ya da kırıkların olușmasına neden olmaktadir (Chadwick ve Dieterich, 1995). Monojenetik volkan bölgelerinde her yapının sadece bir defa püskürdüğü kabul edilmektedir (Walker, 1999). Bu nedenle monojenetik yapıları besleyen magmaların aynı yolu izlediği düșünülemez. Yaklașık iki milyon yıldan tarihsel zamana kadar, sadece belirli zaman aralıklarında püskürmelerin meydana geldiği Kula bölgesinde, Grützner vd. (2013) magmanın Moho Sınııından yüzeye ulașma zamanını 4-11 gün olarak hesaplamıșlardır. Ancak, II. Evreden itibaren lav ve piroklastik ürünlerin içerisinde rastlanılan değișik türdeki ultramafik anklavlar (kümülatlar), Kula volkanizmasında iki önemli kanıtın varlığına ișaret etmektedir:

- Etkili bir fraksiyonel kristalleșme süreci (Çakır vd., 1999; Șen, 2002; Holness ve Bunbury, 2006; Grützner vd., 2013),

- Magmanın yüzeye hızıı bir șekilde yükselmesi (Tokçaer vd., 2005; Holness ve Bunbury, 2006; Grützner vd., 2013). 
Anklavlar (genellikle 3.0-3.3 $\mathrm{g} / \mathrm{cm}^{3}$ ) bazaltik magmaya $\left(2.75 \mathrm{gr} / \mathrm{cm}^{3}\right)$ göre daha yüksek yoğunluğa sahiptir ve çapları $0.1 \mathrm{~mm}$ 'den büyük olduğunda onları tașıyan $10^{3}$ Pas viskoziteye sahip Newtonian magma içinden geçme hızı $1 \mathrm{~cm} / \mathrm{s}^{\prime}$ den büyüktür (Sparks vd., 1977). Lav akıntıları ve piroklastik ürünlerin içerisindeki anklavların yoğunluğu ve büyüklüğü bu hızın aslında çok daha yüksek olduğunu göstermektedir. Nitekim, Kula'daki anklavların ortalama çapı $5 \mathrm{~cm}$ olup, maksimum $30 \mathrm{~cm}$ 'yi bulmaktadır (Șen, 2002). Ayrıca, anklavların varlığının yanı sıra $5.9 \mathrm{~km}^{3}$ lük püsküren magma hacmi de volkanizmanın hızlı bir șekilde gerçekleștiğinin kanıtı sayılabilir (Panter vd., 1994). O nedenle, yukarıda bahsedilen bu iki kanıt birbiri ile çelișmektedir. İkinci kanıtın tersine, birinci kanıta göre anklavların fraksiyonel kristalleșme ile olușumu için zamana intiyaç vardır. Ayrıca, yarı kristalin bir magma kütlesinin yüzeye hızlı bir șekilde çıkması da beklenemez. Bölgedeki astenosferik mantonun etkili bir șekilde yükselmesi 2 milyon yıl önce bașlamaktadır (Seyitoğlu, 1997b; Aldanmaz vd., 2000; Dilek ve Altunkaynak, 2009 ve 2010; Karaoğlu vd., 2010; Ersoy vd., 2010, 2012). Bu dönemde I. Evre bazalt akıntıları olușmaktadır. Anklav tașıyan II.Evre volkanik ürünlerin ilk olușum yașı ise yaklașık 300 bin yıldır. Holness ve Bunbury (2006), II. Evre volkanik ürünlerini olușturan magmanın ilk olarak alt kabuk içerisinde toplandığını, burada fraksiyonel kristalleșmeye uğrayarak yarı eriyik bir hal aldığını ve tam katılașma gerçekleșmeden așağıdan gelen aynı kökenli diğer bir magma tarafından hızlı bir șekilde yüzeye tașındığını ifade etmektedir.

\section{Lav Akıntıları}

KVA'da, I. ve II. Evre'de plato lavları ve III. Evrede 'a'a lavları olmak üzere iki tip lav akıntısı meydana gelmiștir. Bir lav akıntısını tanımlarken kullanılan en önemli parametreler lav akıntısının çıkıș merkezi, yayılımı, kalınlığı, çevre kayaçlarla olan dokanak ilișkisi ve fiziksel özellikleri șeklinde sıralanabilir.

I. Evre Plato bazaltlarına ait çıkıș merkezleri tam olarak belirlenememiștir. Bunun nedeni erozyondan sonra lav akıntılarının günümüzdeki dağılımının çok sınırlı olmasıdır. Bir diğer nedeni ise morfolojisinin düzgün bir plato șeklinde olmasıdır. Plato bazaltları genellikle tekrarlanmalı olarak meydana gelirler ve basamak tipi yapılar oluștururlar (White ve McKenzie, 1989). Ancak, Kula'da meydana gelen bu akıntılar tek bir seviyeden olușmaktadır. I. Evrenin plato bazaltları masif bir görünüme sahiptir. Gözeneklilik oranının düșük olması lavların yeryüzüne yayılmadan önce magmadaki gazların ortamı kolay bir șekilde terkettiğini göstermektedir (Greenough vd., 1999).

II. Evre bazalt akıntıları Kula volkanizmasının en yüksek hacimli faaliyetlerini içermektedir. Çıkıș merkezlerini ise cüruf konileri olușturmaktadır. I. Evre bazaltlarından farklı olarak, belirgin bir fiziksel bozunmaya (soğan kabuğu alterasyonu) uğramıșlardır. Bozunmanın etkili olmadığı yerlerde I. Evre plato bazaltlarına benzerlik göstermektedir. Ancak, soğumaya bağlı olarak gelișen sütun yapıları oldukça düzensizdir.

Püskürme merkezleri belirgin olan III. Evre 'a'a bazalt akıntıları ise morfolojik görüntüsü ve rengi bakımından diğerlerinden oldukça farklıdır. Bloklu dıș yüzeyi, daha masif ve sütun yapılı içyapısı ve akma breșlerinin meydana geldiği tabanı ile karakterize edilmektedir. Lav akarken gazların ortamı terketmesi nedeniyle soğuma hızlı bir șekilde gerçekleșerek, lavın katılașan dıș kabuğu akma hareketi sonucu parça parça kırılarak, üst üste yığıșmaktadır (Cashman vd., 1999). O nedenle akıntının yüzeyi irili ufaklı keskin bloklardan olușmaktadır.

Kula'daki lav akıntıları, tabanından tavanına doğru dikey kesitleri boyunca değișik gözeneklilik oranlarına ve seviyelerine sahiptirler (Aubele vd., 1988). Ayrıca, gözenek çapları ve șekilleri de farklılıklar göstermektedir. Lavın tabanından tavanına doğru gerçekleșen kristalleșmeler (mikrolit olușumu) ve bu sırada yükselen gaz kabarcıkları akıntının içerisinde gözenekli seviyelerin olușmasına neden olmaktadır (Sahagian, 1985). Kabarcıklar tabandan yukarı yükseldikçe küçük çaplı olanlar kristal önlerinde tutularak ilerlemesi durdurulurken, büyük çaplılar kaçarak akıntının üst seviyelerine doğru ilerler (Sahagian vd., 2002). Orta seviyeye yaklașıldığında gözenek hacmindeki küçülme, bazalt akıntısının alt-orta ve üst kısmının farklı soğuma hızına sahip olmalarından kaynaklanmaktadır (McBirney 
ve Murase, 1971; Sparks 1978). Akıntının iç kısmında soğuma daha yavaș olduğu için buradaki kabarcıklar birbirleri ile birleșmek için yeteri kadar zaman bularak, soğumanın daha hızlı olduğu üst seviyelere doğru hareket etmektedirler (Sahagian vd., 2002). Lavların iç kısımlarının gözenek bakımından fakir olmasının nedeni de bu șekilde açıklanabilir. Mikrolit içeriği zengin olan bazaltik magmalarda kabarcık büyümesi sınırlıdır (Gonnermann and Houghton 2012). Gözeneklilik miktarı en düșük olan I. Evre plato bazaltları diğer evrelerdeki bazaltlardan daha fazla mikrolit içeriğine sahiptir.

Gözenek hacmindeki değișiklikler, uçucuların miktarına ve gözenek çekirdeklenme hızındaki değișikliklere bağlıdır (McBirney ve Murase, 1971). Eğer lav akıntısının üst seviyeleri normalden daha hızlı soğursa, gözenek hacmi küçülmekte fakat gözeneklilik miktarı artmaktadır. Bunun nedeni gözenek hücrelerinin lavın hızı soğumasına bağlı olarak gelișimini tam olarak tamamlayamadıklarından kaynaklanmaktadır (Sparks 1978).

\section{Cüruf Konileri}

KVA'daki cüruf konilerinin birçoğu cüruf geridüșme ürünlerinden olușmaktadır. Bazılarında ise lav ve cüruf katmanlarının ardalanmalı șekilde tekrarlandığı gözlenmektedir. Bu durum faaliyetin patlamalı volkanizmadan, efüzif volkanizmaya geçiși ile meydana gelmektedir. Ancak, lav katmanlarının yer almadığı cüruf konilerinin olması, o koni için efüzif faaliyetin gerçekleșmediği anlamına gelmemektedir. Özellikle karnıyarık tipi cüruf konileri, efüzif faaliyetin en önemli kanıtı olarak gösterilebilir. Koniyi olușturan cüruf geri-düșme ürünleri siyah veya kırmızı renktedirler. Bu tür renk farklııkları magmanın çıkıș noktasının değiștiğini göstermektedir. Kırmızı renkli cüruflar çıkıș noktasına yakın kesimlerde bulunmakta ve sıcak bir oksitlenmeyi karakterize etmektedir (Carmichael, I.S.E., 1991; Hanson vd., 2008).

Cüruf ve küllerin pekișme oranı düșük olduğu için erozyona karșı nispeten duyarsızlardır. Bu nedenle koninin yüksekliğinde, krater derinliğinde ve yamaç eğiminde azalmalar gözlenecektir. Cüruf konilerindeki așınma durumunu ve dolayısıyla yaș ilișkilerini incelemek amacıyla Wco/Hco oranı ile $\theta$ değeri kullanılmıștır. Bu șekilde aynı evreye ait koniler arasında da bir takım karșılaștırmalarda bulunmak mümkün olmaktadır. Mevcut veriler, așınma miktarı arttıkça II. Evre cüruf konilerinde Wco/Hco oranın artı̆̆ııı, $\theta$ değerinin azaldığını göstermektedir (Șekil 11). Cüruf konilerinin așınma miktarını daha iyi belirlemek amacıyla Kula volkanik bölgesinin ASTER GDEM v2 Sayısal Yükseklik Modelinden türetilmiș eğim haritası kullanılmıștır (Şekil 12). Açıkça görülmektedir ki; 10, 41, 44, 58, 59, 60, 62 ve 63 numaralı III. Evreye ait koniler daha koyu renk tonlarına sahip olup, en yüksek yamaç eğimi değerlerine sahiptirler. Diğer taraftan, II. Evreye ait 7, 9, 16, 40, 49, 53, 54, 56 , ve 64 numaralı (Șekil 12'de italik ve noktalı olarak belirtilmiștir) koniler de belirtilen III. Evre konilerine yakın renk tonlarına sahip olmaktadır. Bu nedenle II. Evreye ait olan bu konilerin yaș bakımından III. Evre konilerine yakın olabileceği düșünülmektedir. Ancak, koniler sadece cüruf yığınlarından olușmamaktadır (Șekil 4d). Koniyi olușturan lav katmanları ve sıçratma lav parçaları varlığının așınma miktarını önemli ölçüde yavașlatacağı da unutulmamalıdır (Wood, 1980). Riedel vd. (2003) püskürmenin lav sıçratmaları șeklinde gerçekleșmesi durumunda, koni yüzeyinde düșen yarı eriyik parçaların birbirleri ile kolayca kaynaklandığını ve buna bağıı olarak dreneja izin vermeyen katmanların oluștuğunu ifade etmișlerdir. Böylece konilerin taban çapı sabit kalırken, yükseklik değeri artıș gösterecek ve Wco/Hco değeri düșecektir. Bașka bir ifadeyle, tüm konilerin morfometrik sınıflaması yapıldığında, koni yașı ılsa bile genç konilerin arasında yer alabilmektedir.

\section{Maarlar}

Eğim haritasından da anlașıldığı gibi morfolojik olarak en belirgin maar Çukurada Maar'ıdır (M4, Șekil 12). Bunun nedeni diğerlerine göre daha derin bir patlama hikayesine sahip olmasındandır. Diğer maar türleri düșük eğim yamaçlı tüf halkalarından oluștukları için eğim haritasında ayırt edilememektedir. Maar olușumunu takiben, lav çıkıșı ile birlikte maar kenarında veya içerisinde koni / konilerin olușması mümkün olmaktadır. Bu olay volkanizmanın hidromagma- 


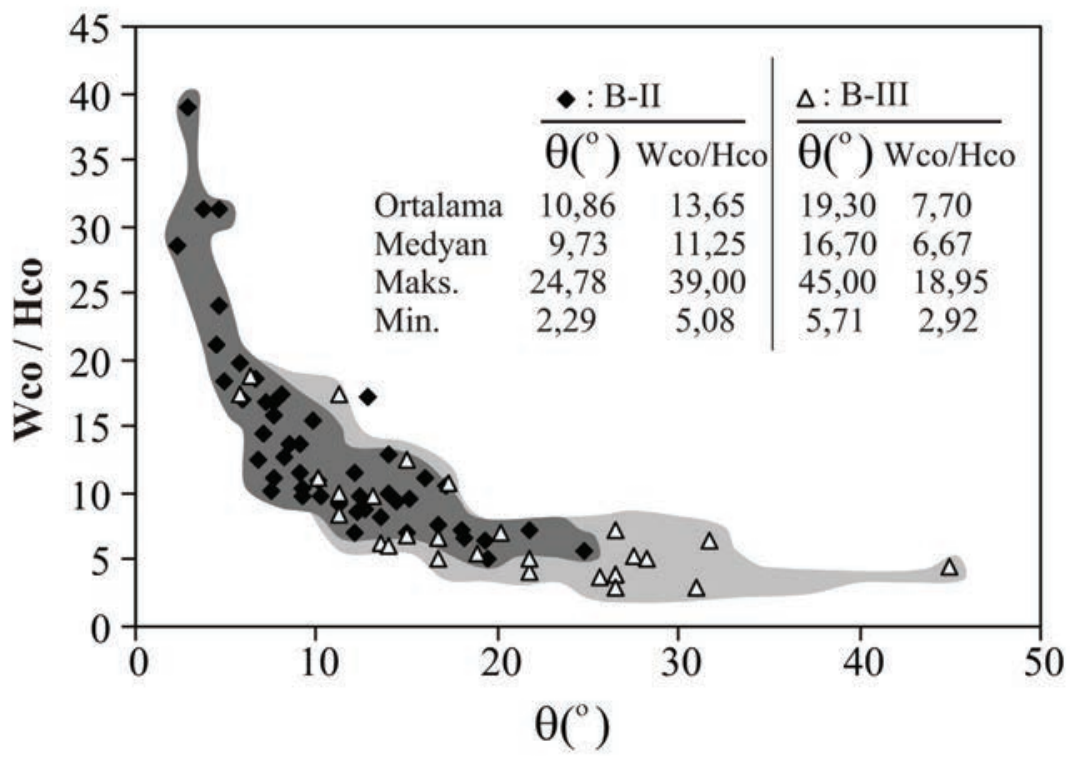

Șekil 11. Cüruf konilerinin așınma derecesini gösterir yamaç eğimi $(\theta)$ - koni taban çapının yüksekliğe oranı (Wco/Hco) grafiği.

Figure 11. The diagram of slope angle $(\theta)$ versus cone basal diameter to height ratio (Wco/Hco).

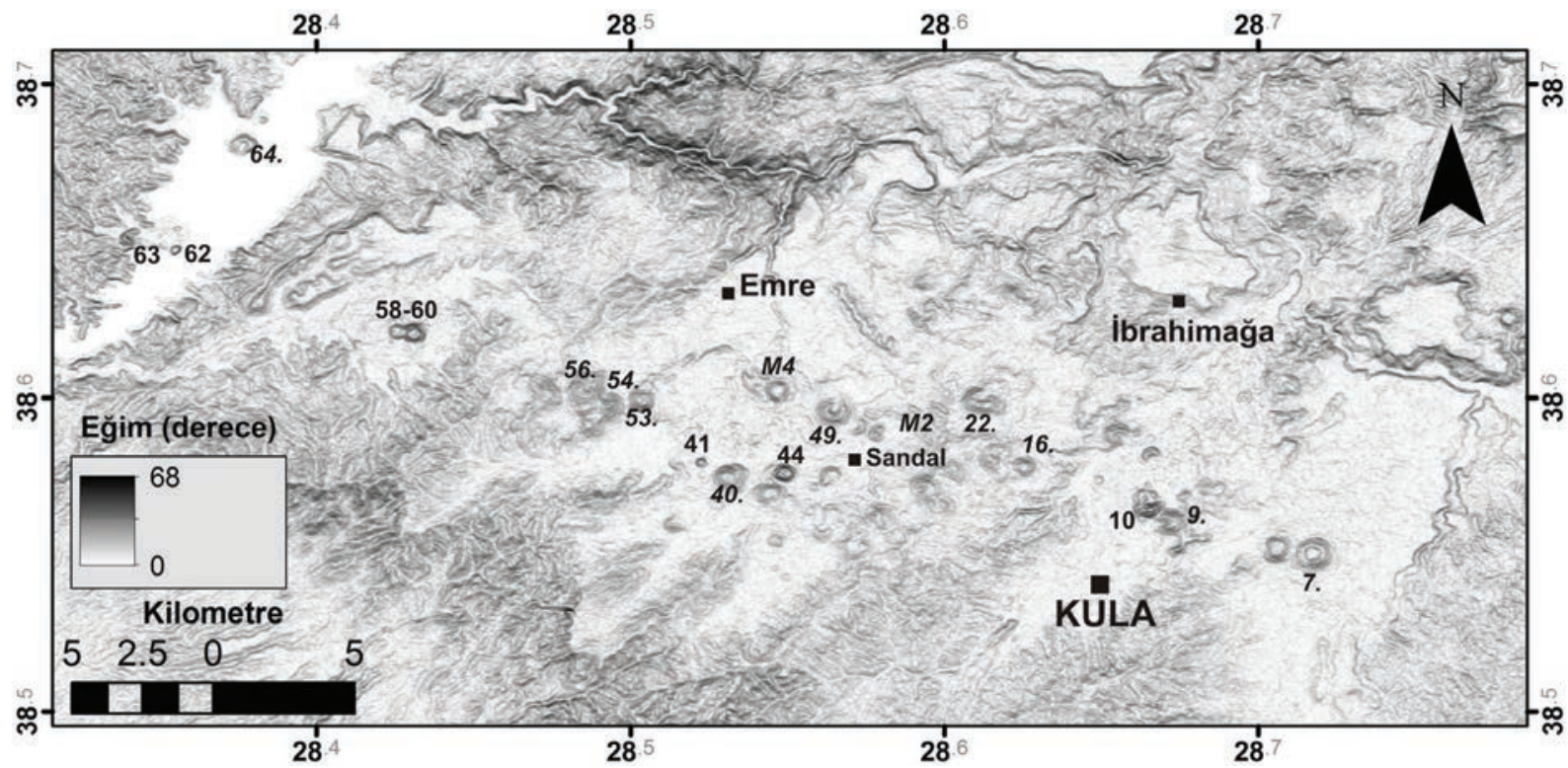

Șekil 12. Kula volkanik bölgesinin ASTER GDEM v2 Sayısal Yükseklik Modelinden türetilmiș eğim haritası. Koordinat sistemi CKS, datum WGS84. Koni isimleri için Çizelge 2'ye bakınız.

Figure 12. Slope map of Kula volcanic region derived from Digital Elevation Model of ASTER GDEM v2. Coordinate system GCS, datum WGS84. Look at Table 2 for the cone name.

tik (freatomagmatik) faaliyetten magmatik faaliyete dönüșmesi șeklinde açıklanabilir. KVA'daki üç tüf halkasının (M1, M3 ve M4) krater içleri ve sırtları kısmen veya tamamen örtülmüștür. KVA gibi cüruf konilerinin yoğun olduğu alanlarda, tüf halkalarının morfolojik olarak ayırt edilmesi bazen zor olmaktadır. Bu nedenle arazide maar olușumunu karakterize eden taban yayı- 
lımı ürünlerinin detaylı bir șekilde incelenmesi gerekmektedir. Taban yayılımı ürünleri kendisine özgü bir takım sedimanter yapılar içermektedir. Bu sedimanter yapıların arazideki en önemli özelliği, taban yayılımı ürünlerinin nereden gelebileceğini (muhtemel patlama merkezi yönü) ve ne yöne doğru ilerlediğini göstermesidir (Fisher ve Schmincke, 1984; Cas ve Wright, 1987; Brand ve White, 2007; Ort ve Núñez, 2009). Sedimanter yapılardan biri çapraz tabakalı kumul tepeciklerdir. Akıș çizgilerinin birbirini kestiği yer patlama merkezi yönünü göstermektedir (Șekil 5e). Bir diğeri ise, çarpmaçökme yapısıdır. Balistik bir yörüngede hareket eden bloklar taban yayılımı ürünlerinin üzerine düștüklerinde, çarptığı yerde asimetrik bir çökme meydana getirirler. Asimetrik çökmede kül katmanlarının en fazla sıkıșıp, deformasyona uğradığı yer, bloğun ilerleme yönünü vermektedir (Șekil 5e).

Maarlarda çap ve derinlik oranı (Do/d) maarların așınma miktarını ölçmek amacıyla kullanıımıștır. Bu oran en genç maarlarda 4 - 6 arasında olup, yașlandıkça așınmanın ilerleyip krateri doldurmasıyla yaklașık 10'u bulmaktadır (Wood, 1974; Kienle vd., 1980; Cas ve Wright, 1987).
Kula'daki maarların Do/d değerleri, 8 ile 40 arasında değișmektedir. Ancak, bu tür yorumlar yapilırken krater içinin sonraki püskürmelerle veya așınma ile dolabileceği göz önüne alınmalıdır (Abrams ve Siebe, 1994). Nitekim, Kula'daki maarların krater kenarlarında çıkan cüruf konisine ait projeksiyon ve lav ürünleri krater içini kısmen doldurulmuștur. Bu nedenle "d" değeri küçülmüș ve Do/d oranı artmıștır (Șekil 10).

Çizelge 3'teki $V_{\jmath}$ değerleri karșılaștırıldığında en fazla jüvenil magma içerğinin Cemal Tepe Maarı'na (M2) ait olduğu görülmektedir. Krater çapı büyüdükçe çıkan malzeme miktarı artmaktadır. Bu iki parametre arasında doğrusal bir ilișki bulunmaktadır (Șekil 13). Șekil 13'te, noktalı çizgi ile gösterilen doğrunun denklemi $\mathrm{D}=0.97 \mathrm{~V}^{0.36}$ olarak belirlenmiștir. Burada, $\mathrm{D}$ krater çapını ve $V_{E}$ püsküren malzemenin hacmini temsil etmektedir. Gri alanla taranan kısım Endenozya'daki Lamongan volkanik bölgesine (LVF) aittir (Carn, 2000). Kula bölgesine ait 5 maarın düștüğü bölge siyahla taranmıș olup krater çapı ve püsküren malzeme miktarı bakımından LVF'den daha yüksek değerlere sahiptir. Kesiksiz çizginin eğim denklemi ise $D=0,11$ $x V^{0.42}$ 'dir ve cüruf konilerini temsil etmektedir.

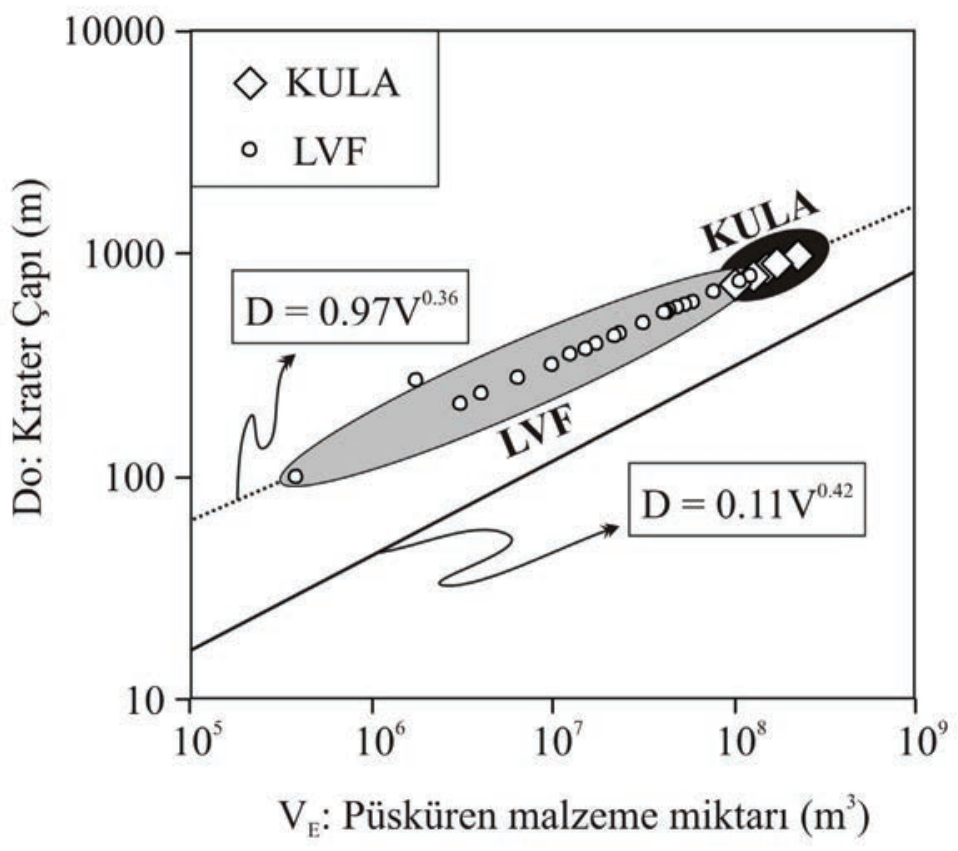

Șekil 13. Krater çapına karșılık (Do) püskürme miktarı (VE) grafiği (Sato ve Tanuguchi, 1997).

Figure 13. The diagram of crater diameter (Do) versus ejecta volume (VE) (Sato and Tanuguchi, 1997). 
Görüldüğü gibi freatomagmatik püskürmelerin krater çapları cüruf konilerinkinden 2 ile 5 arasında daha geniș olmaktadır. Buna karșılık benzer hacimde piroklastik malzeme üretmektedirler.

Bölgede yașlandırma ile ilgili çeșitli çalıșmalar yapılmıș ve halen de devam etmektedir. Ancak monojenetik volkanların sayısı oldukça yüksek olduğu için bundan sonraki yapılacak yaș tayinleri için konilerin așınma oranları gruplandırılıp, bu gruplara göre örnek seçimi daha doğru olacaktır. Ayrıca, Bunbury (1996)'nin, Kula bazalt akıntılarının hacmini 2,3 $\mathrm{km}^{3}$ bulduğu düșünülürse, Kula'daki piroklastik ürünlere ait hacimlerin hiç de küçümsenmeyecek ölçekte olduğu rahatlıkla görülmektedir. Bunbury (1996) tarafından hesaplanan lavların hacmine piroklastik ürünlere ait değerler de eklendiğinde KVA'daki volkanik ürünlerin toplam hacmi $\sim 5,9 \mathrm{~km}^{3}$ hesaplanmaktadır. Bu nedenle Batı Anadolu'da "gerilme katsayısı" hesaplanırken, Kula volkanizmasını olușturmak için üretilen magma miktarı daha da önem kazanmaktadır.

\section{KATKI BELIRTME}

Bu çalıșma 1997-2002 yılları arasında, Hacettepe Üniversitesi Jeoloji Mühendisliği Bölümünde, yürütücülüğünü Prof. Dr. Hasan BAYHAN'ın yaptığı, TÜBITAK YDABÇAG-398 nolu bilimsel araștırma projesi ve Hacettepe Üniversitesi 01 T07 604002 nolu Araștırma Fonunun (Bilimsel Araștırma Birimi) katkılarıyla hazırlanmıștır. Yazarlar değerli, gerekli ve yapıcı katkılarından dolayı hakemlere teșekkür ederler.

\section{KAYNAKLAR}

Abrams, M. J. and Siebe, C., 1994. Cerro Xalapaxco: unusual tuff cone with multiple explosion craters, in central Mexico (Puebla). Journal of Volcanology and Geothermal Research, 63, 183-199.

Aldanmaz, E., Pearce, J.A., Thirlwall, M.F., and Mitchell, J.G., 2000. Petrogenetic evolution of late Cenozoic, post-collision volcanism in western Anatolia, Turkey. Journal of Volcanology and Geothermal Research, 102, 67-95.
Alıcı, P. Temel, A., and Gourgaud, A., 2002. Pb$\mathrm{Nd}-\mathrm{Sr}$ isotope and trace element geochemistry of Quaternary extension-related alkaline volcanism: a case study of Kula region (western Anatolia, Turkey). Journal of Volcanology and Geothermal Research, 115, 487-510.

Aramaki, S. Hayakawa, Y., Fujii, T., Nakamura, K., and Fukuoka, T., 1986. The October 1983 eruption Miyakejima volcano. Journal of Volcanology and Geothermal Research, 29, 203-229.

Aubele ,J.C., Crumpler, L.S., and Elston, W.E., 1988. Vesicle zonation and vertical structure of basalt flows. Journal of Volcanology and Geothermal Research, 35, 349-374.

Barka, A. A., 1992. The North Anatolian Fault Zone. Annales Tectonicae, 6: 164-195

Borsi, M., Ferrara, G., Innocenti, F., and Mazzuoli, R., 1972. Geochoronology and petrologoy of recent volcanics of Eastern Aegeab Sea, Bulletin of Volcanology, 36 (1), 473-496.

Bozkurt, E., and Park, R.G. 1994. Southern Menderes Massif: an incipient metamorphic core complex in western Anatolia. Journal of the Geological Society, London, 151, 213-216.

Bozkurt, E., 2001. Neotectonics of Turkey-a synthesis. Geodinamica Acta, 14, 3-30

Bozkurt, E., 2003. Origin of NE-trending basins in western Turkey. Geodinamica Acta, $16,61-81$.

Bozkurt, E., and Sözbilir, H., 2004. Tectonic evolution of the Gediz graben: field evidence for an episodic, two-stage extension in Western Turkey. Geological Magazine, 141, 63-79.

Bozkurt, E., and Mittwede, S.K., 2005. Evolution of Neogene extensional tectonics of western Turkey. Geodinamica Acta, 18, 153-165.

Bozkurt, E., and Rojay, B., 2005. Episodic, twostage Neogene extension and shortterm intervening compression in western Anatolia: field evidence from the 
Kiraz Basin and Bozdağ Horst. Geodinamica Acta, 18, 299-316.

Brand, D., and White, C.M., 2007. Origin and stratigraphy of phreatomagmatic deposits at the Pleistocene Sinker Butte Volcano, Western Snake River Plain, Idaho. Journal of Volcanology and Geothermal Research., 160, 319-339.

Büttner, R., and Zimanowski, B., 1998. Physics of thermohydraulic explosions. Physical Review E, 57, 5726-5729.

Bunbury, J. M. R., 1996. The Kula Volcanic Field, western Turkey: the devolopment of a Holocene alkali basalt province and the adjacent normal-faulting graben. Geological Magazine, 133 (3), 275-283.

Bunbury, J.M., Hall, L., Anderson, G.J., and Stannard, A., 2001. The determination of fault movement history from the interaction of local drainage with volcanic episodes. Geological Magazine, 138, 185-192

Carmichael I.S.E., 1991. The redox states of basic and silicic magmas: $A$ reflection of their source regions? Contributions to Mineralogy and Petrology, 106, 129-141

Carn, S. A., 2000. The Lamongan volcanic field, East Java, Indonesia: physical volcanology, historic activity and hazards. Journal of Volcanology and Geothermal Research, 95, 81-108.

Cas, R.A.F., and Wright, J.V., 1987. Volcanic Successions. Modern and Ancient. Allen and Unwin, London, 528p.

Cashman, K. V., Thornber, C., and Kauahikaua, J. P., 1999. Cooling and crystallization of lava in open channels, and the transition of pahoehoe lava to 'a'a. Bulletin of Volcanology, 61, 306-323.

Cebriá, J.M., Martín-Escorza, C., López-Ruiz, J., Morán-Zenteno, D.J., and Martiny, B.M., 2011. Numerical recognition of alignments in monogenetic volcanic areas: Examples from the MichoacánGuanajuato Volcanic Field in Mexico and Calatrava in Spain. Journal of Volcanology and Geothermal Research, 201, 73-82.
Chadwick, W. W., and Dieterich, J. H., 1995. Mechanical modelling of circumferential and radial dike intrusion on Galapagos volcanoes. Journal of Volcanology and Geothermal Research, 66, 37-52.

Cohen, H.A., Dart, C.J., Akyüz, H.S., and Barka, A., 1995. Syn-Rift Sedimentation and Structural Development of the Gediz and Büyük-Menderes Graben, Western Turkey. Journal of Geological Society of London, 152, 629-638.

Çakir, Ü., Aydar, E., Sen, E., and Bayhan H., 1999. Petrographical Characteristics of the Ultramafic-Mafic Nodules in Alkali Basalts from Kula Province, Western Anatolia -Turkey. EUG 10, Journal of Conference, Abstracts, Vol. 4, Number 1 (Peri-Alpine Cenozoic Volcanism, Tectonics and Sedimentation)

Çiftçi, B., and Bozkurt, E., 2009. Evolution of the Miocene sedimentary fill of the Gediz Graben, SW Turkey. Sedimentary Geology, 216, 49-79.

Çoban, H., 2007. Basalt magma genesis and fractionation in collision and extension related provinces: a comparison between eastern, central and western Anatolia. Earth Science Reviews, 80, 219-238.

Dilek, Y., and Altunkaynak, Ș., 2009. Geochemical and temporal evolution of Cenozoic magmatism in western Turkey: mantle response to collision, slab breakoff, and lithospheric tearing in an orogenic belt. In: van Hinsbergen DJJ, Edwards MA, Govers R (eds) Collision and collapse at the Africa-Arabia-Eurasia Subduction Zone, 311. Geological Society London Special Publications, London, 213-233.

Dilek, Y., and Altunkaynak, Ș., 2010. Geochemistry of Neogene-Quaternary alkaline volcanism in western Anatolia, Turkey, and implications for the Aegean mantle. International Geology Review, 52, 4-6, 631-655.

Dragoni, M., Piombo, A., and Tallarico, A., 1995. A model for the formation of lava tubes by roofing over a channel. Journal of Geophysical Research, 100, 8435-8447. 
Dragoni, M., and Santini S., 2007. Lava flow in tubes with elliptical cross sections. Journal of Volcanology and Geothermal Research, 160, 239-248

Emre, T., 1996. Gediz grabeninin jeolojisi ve tektoniği (Geology and tectonics of the Gediz graben). Turkish Journal of Earth Science, 5, 171-185.

Emre, T., and Sözbilir, H., 2007. Tectonic evolution of the Kiraz Basin, Küçük Menderes Graben: evidence for compression/ uplift-related basin formation overprinted by extensional tectonics in West Anatolia. Turkish Journal of Earth Science, 16, 441-470.

Ercan, T., Türkecan, A., Dinçel, A., ve Erdoğdu, G., 1983. Kula-Selendi (Manisa) Dolaylarının Jeolojisi. Jeoloji Mühendisliği Dergisi, 17, 3-28.

Erinç, S., 1970. Kula-Adala arasında genç volkan röliyefi. i..Ü. Coğrafya Enstitüsü Dergisi, 17, 148-167.

Erkül, F., Helvacı, C., and Sözbilir, H., 2005. Evidence for two episodes of volcanism in the Bigadic borate basin and tectonic implications for Western Turkey. Geological Journal, 40, 545-570.

Ersoy, E., and Helvacl, C., 2007. Stratigraphy and geochemical features of the Early Miocene bimodal (ultrapotassic and calc-alkaline) volcanic activity within the NE-trending Selendi Basin, Western Anatolia, Turkey. Turkish Journal of Earth Science, 16, 117-139.

Ersoy, Y., Helvacı, C., Sözbilir, H., Erkül, F., and Bozkurt, E., 2008. A geochemical approach to Neogene-Quaternary volcanic activity of western Anatolia: an example of episodic bimodal volcanism within the Selendi Basin, Turkey. Chemical Geology, 30, 265-282.

Ersoy, E. Y., Helvacı, C., and Sözbilir, H., 2010. Tectono-stratigraphic evolution of the NE-SW- trending superimposed Selendi basin: Implications for late Cenozoic crustal extension in Western Anatolia, Turkey. Tectonophysics, 488, 210-232.

Ersoy, E. Y., Helvacı, C., and Palmer, M. R., 2011. Stratigraphic, structural and geochemi- cal features of the NE-SW-trending $\mathrm{Ne}$ ogene volcano-sedimentary basins in western Anatolia: implications for associations of supradetachment and transtensional strike-slip basin formation in extensional tectonic setting. Journal of Asian Earth Sciences, 41, 159-183

Ersoy, E. Y., Helvaci, C., and Palmer, M. R., 2012. Petrogenesis of the Neogene volcanic units in the NE-SW-trending basins in western Anatolia, Turkey. Contributions to Mineralogy and Petrology, 163, 379-401.

Fisher, R.V., and Schmincke, H.U., 1984. Pyroclastic rocks. Berlin: Springer-Verlag, $472 p$.

Galindo I., and Gudmundsson A., 2012. Basaltic feeder dykes in rift zones: geometry, emplacement, and effusion rates. Natural Hazards and Earth Systems Sciences, 12: 3683- 3700

Gessner, K., Ring, U., Christopher, J., Hetzel, R., Passchier, C.W., and Güngör, T., 2001. An active bivergent rolling-hinge detachment system: central Menderes metamorphic core complex in western Turkey. Geology, 29, 611-14.

Gonnermann, H.M., and Houghton, B.F., 2012. Magma degassing during the Plinian eruption of Novarupta, Alaska, 1912. Geochemistry, Geophysics, Geosystems, 13, Q10009

Göksu, Y., 1978. The TL age determination of fossil human footprints. Archaeo-Physica, 10, 445-462.

Greenough, J.D., Lee, C.Y., and Fryer, B.J., 1999. Evidence for volatile-influenced differentiation in a layered alkali basalt flow, Penghu Islands, T aiwan. Bulletin of Volcanology, 60, 412-424.

Grützner, T., Prelevic, D., and Akal C., 2013. Geochemistry and origin of ultramafic enclaves and their basanitic host rock from Kula Volcano, Turkey. Lithos 180181, 58-73.

Gudmundsson, A., 2002. Emplacement and arrest of sheets and dykes in central volcanoes, Journal of Volcanology and Geothermal Research, 116, 279-298. 
Gudmundsson, A., 2012. Magma chambers: formation, local stresses excess pressures, and compartments. Journal of Volcanology and Geothermal Research, 237-238, 19-41.

Güleç, N., 1991. Crust-mantle interaction in Western Turkey: implications from $\mathrm{Sr}$ and $\mathrm{Nd}$ isotope geochemistry of Tertiary and Quaternary volcanics. Geological Magazine, 128/5, 417-435.

Hakyemez, H. Y., Erkal, T., and Göktaș, F., 1999. Late Quaternary evolution of the Gediz and Büyük Menderes grabens, Western Anatolia, Turkey. Quaternary Science Review, 18, 549-554.

Hanson, S.L., Falster, A.U., and Simmons, W.B., 2008. Mineralogy of Fumarole Deposits: At Sunset Crater Volcano National Monument Northern Arizona. Rocks \& Minerals, 83 (6), 534-546.

Hasenaka, T., and Carmichael, I. S. E., 1985. The cinder cones of Michoacan-Guanajuato, Central Mexico: their age, volume and distribution, and magma discharge rate. Journal of Volcanology and Geothermal Research, 25, 105-124.

Helvacı, C., 1995. Stratigraphy, mineralogy, and genesis of the Bigadiç borate deposits, Western Turkey. Economic Geology, 90, 1237-1260.

Helvacı, C., and Yağmurlu, F., 1995. Geological setting and economic potential of the lignite and evaporite-bearing Neogene basins of Western Anatolia, Turkey. Israel Journal of Earth Science, 44, 91105.

Holness, M. B., and Bunbury, J. M., 2006. Insights into continental rift-related magma chambers: Cognate nodules from the Kula Volcanic Province, Western Turkey. Journal of Volcanology and Geothermal Research, 153, 241-261.

Innocenti, F., Agostini, S.G., Doglioni, C., Manetti, P., and Tonarini, S., 2010. Geodynamic evolution of the Aegean: constraints from the Plio-Pleistocene volcanism of the Volos-Evia area. Journal of the Geological Society, London,167, 475-489.
Ișık, V., Tekeli, O., and Seyitoğlu G., 2004. The ${ }^{40} \mathrm{Ar} /{ }^{39} \mathrm{Ar}$ age of extensional ductile deformation and granitoid intrusions in the northern Menderes core complex: implications for the initiation of extensional tectonics in western Turkey. Journal of Asian Earth Sciences, 23, 555-566.

Karaoğlu, Ö., Helvacı, C., and Ersoy, E.Y., 2010. Petrogenesis and ${ }^{40} \mathrm{Ar} /{ }^{39} \mathrm{Ar}$ Geochronology of the Volcanic Rocks of the UșakGüre basin, western Türkiye. Lithos, 119, 193-210.

Keszthelyi, L., and Self, S., 1998. Some physical requirements for the emplacement of long basaltic lava flows. Journal Of Geophysıcal Research, 103, BII, 2744727464.

Kienle, J., Kyle, P. R., Self, S., Motyka, R. J., and Lorenz, V., 1980. Ukinrek Maars, Alaska: I. April 1977 eruption sequence, petrology and tectonic setting. Journal of Volcanology and Geothermal Research, 7, 11-37.

Klügel, A., Hansteen, T.H., and Galipp, K., 2005. Magma storage and underplating beneath Cumbre Vieja volcano, La Palma (Canary Islands). Earth and Planetary Science Letters, 236, 211-226.

Koçyiğit, A., 2005. The Denizli graben-horst system and the eastern limit of western Anatolian continental extension: basin fill, structure, deformational mode, throw amount and episodic evolutionary history, SW Turkey. Geodinamica Acta, 18, 167-208.

Le Bas, M.J., Le Maitre, R.W., Streckeisen, A., and Zanetti, B., 1986. A chemical classification of volcanic rock based on the total alkali - silica diagram. Journal of Petrology, 27, 745-750

Lips, A.L.W., Cassard, D., Sözbilir, H., Yılmaz, H., and Wijbrans, J., 2001. Multistage exhumation of the Menderes Massif, western Anatolia (Turkey). International Journal of Earth Sciences, 89, 781-792.

Macdonald, G. A., 1972. Volcanoes. PrenticeHall, Englewood Cliffs, N. J., 510p

Manga, M., Patel, A., Dufek, J., and Kite, E.S., 2012. Wet surface and dense atmosp- 
here on early Mars suggested by the bomb sag at Home Plate, Mars. Geophysical Research Letters, 39, L01202, 1-5.

McBirney, A.R. and Murase, T., 1971. Factors governing the formation of pyroclastic rocks. Bulletin of Volcanology, 34: 372384

Miyashiro, A., 1978, Nature of alkalic volkanic rock series. Contributions to Mineralogy and Petrology, 66, 91-104.

Okay, A., Zattin, M., and Cavazza, W., 2010. Apatite fission-track data for the Miocene Arabia-Eurasia collision. Geophysical Research Abstracts, Vol.12. EGU2010-3942.

Ort, M.H., and Carrasco-Núñez G., 2009. Lateral vent migration during phreatomagmatic and magmatic eruptions at Tecuitlapa Maar, east-central Mexico. Journal of Volcanology and Geothermal Research, 181, 67-77.

Panter, K. S., Mclntosh, W. C., and Smellie, J. L., 1994. The volcanic history of Mount Sidley, a major alkaline volcano in Marie Byrd Land, Antarctica. Bulletin of Volcanology, 56 361-376.

Porter, S. C., 1972. Distribution, morphology, and size frequency of cinder cones on Mauna Kea volcano, Hawaii. Geological Society of America Bulletin, 83, 36073612.

Purvis, M., and Robertson, A., 2004. A pulsed extension model for the neogene-recent E-W-trending Alașehir Graben and the NE-SW-trending Selendi and Gördes Basins, Western Turkey. Tectonophysics, 391, 171-201.

Purvis, M., and Robertson, A., 2005. Miocene sedimentary evolution of the NE-SWtrending Selendi and Gördes basins, western Turkey: implications for extensional processes. Sedimentary Geology, 174, 31-62.

Ramos V.A., and Folguera A., 2011. Payenia volcanic province in the Southern Andes: An appraisal of an exceptional Quaternary tectonic setting. Journal of
Volcanology and Geothermal Research, 201, 53-64.

Riedel, C., Ernst, G.G.J., and Riley, M., 2003. Controls on the growth and geometry of pyroclastic constructs: Journal of Volcanology and Geothermal Research, 127, 121-152.

Ring, U., Johnson, Hetzel, R., and Gessner, K., 2003. Tectonic denudation of a Late cretaceous-Tertiary collisional belt: regionally symmetric cooling patterns and their relation to extensional faults in the Anatolide belt of western Turkey. Geological Magazine, 140, 421-441

Ring, U., and Layer, P.W., 2003. High-pressure metamorphism in the Aegean, eastern Mediterranean: underplating and exhumation from the Late Cretaceous until the Miocene and Recent above the retreating Hellenic subduction zone. Tectonics, 22, 1022, 6.1-6.23.

Rojay, B., Toprake, V., Demirci, C., and Süzen, L., 2005. Plio-Quaternary evolution of the Küçük Menderes Graben southwestern Anatolia, Turkey. Geodinamica Acta, 18, 317-331.

Rossi, M.J., and Gudmundsson, A. 1996. The morphology and formation of flow-lobe tumuli on Icelandic shield volcanoes. Journal of Volcanology and Geothermal Research, 72, 3-4, 291-308.

Rubin, A. M., and Pollard, D. D., 1088. Dike-induced faulting in rift zones. Geology, 16 , 413-417.

Sahagian, D. L., 1985. Bubble migration and coalescence during the solidification of basaltic lava flows. The Journal of Geology, 93, 205-211.

Sahagian, D.L., Proussevitch, A.A., and Carlson, W.D., 2002. Analysis of Vesicular Basalts and Lava Emplacement Processes for Application as a Paleobarometer / Paleoaltimeter. The Journal of Geology, 110, 671-685.

Sato H., and Taniguchi, 1997. Relationship between crater size and ejecta volume of recent magmatic and phreato-magmatic eruptions: Implications for energy 
partitioning. Geophysical Research Letters, 24/3, 205-208.

Schumacher, R., and Schmincke, H.S. 1991. Internal structure and occurrence of accretionary lapilli - a case study at Laacher See Volcano. Bulletin of Volcanology, 53, 612-634.)

Seyitoğlu, G., and Scott, B.C., 1991. Late Cenozoic crustal extension and basin formation in west Turkey. Geological Magazine, 128, 155-166.

Seyitoğlu, G., and Scott, B.C., 1992. Late Cenozoic volcanic evolution of the NE Aegean region. Journal of Volcanology and Geothermal Research, 54, 157-176.

Seyitoğlu, G., and Scott, B.C., 1994a. Late Cenozoic basin development in west Turkey: Gördes basin tectonics and sedimentation. Newsletter Stratigraphy, 131, 133-142.

Seyitoğlu, G., and Scott, B.C., 1994b. Neogene palynological and isotopic age data from Gördes basin, West Turkey. Newsletter Stratigraphy, 31, 133-142.

Seyitoğlu, G., 1997a. The Simav graben: an example of young E-W trending structures in the late Cenozoic extensional system of Western Turkey. Turkish Journal of Earth Science, 6, 135-141.

Seyitoğlu, G., 1997b. Late Cenozoic tectonosedimentary development of the Selendi and Ușak-Güre basins: a contribution to the discussion on the development of east-west and north trending basins in Western Turkey. Geological Magazine, 134, 163-175.

Seyitoğlu, G., Tekeli, O., Emen, Ü., Șen, Ș., and Ișı, V., 2002. The role of the flexural rotation/rolling hinge model in the tectonic evolution of the Alașehir graben, western Turkey. Geological Magazine, 139, 15-26.

Seyitoğlu, G., Alçiçek, M.C., Ișık, V., Alçiçek, H., Mayda, S., Varol, B., YIlmaz,I., and Esat, K., 2009. The stratigraphical position of Kemiklitepe fossil locality (Ușak-Eșme) revisited: Implications for the Late Cenozoic sedimentary basin development and extensional tectonics in Western Turkey. Neues Jahrbuch für Geologie und Paläontologie, 251, 1-15.

Sheridan, M.F., and Wohletz, K. H., 1983. Hydrovolcanism: basic considerations and review. Journal of Volcanology and Geothermal Research, 17, 1-29.

Sözbilir, H., 2002. Geometry and origin of folding in the Neogene sediments of the Gediz Graben, western Anatolia, Turkey. Geodinamica Acta, 15, 277-288.

Sözbilir, H., 2005. Oligo-Miocene extension in the Lycian orogen: evidence from the Lycian molasse basin, SW Turkey. Geodinamica Acta, 18, 255-282.

Sparks, R. S. J., Pinkerton, H., and Macdonald, R., 1977. The transport of xenoliths in magmas. Earth an Planetary Science Letters, 35, 234-238.

Sparks, R. S. J., 1978. The dynamics of bubble formation and growth in magmas: A rewiew and analysis. Journal of Volcanology and Geothermal Research, 3, 1-37

Șen, E., 2002. Kula Bölgesi (Batı Anadolu, Türkiye) volkanizmasının volkanolojik-petrolojik gelișiminin incelenmesi. Doktora Tezi, Fen Bilimleri Enstitüsü, Hacettepe Üniversitesi, Ankara, Türkiye, 269 sayfa

Șengör, A.M.C., and Yilmaz, Y. 1981. Tethyan evolution of Turkey: a plate tectonic approach. Tectonophysics, 75: 181-241.

Tekkaya, I., 1976. Insanlara ait fosil ayak izleri. Yeryuvarı ve İnsan, 1/2, 8-10.

Tokçaer, M., Agostini, S., and Savașçın, M.Y., 2005. Geotectonic setting and origin of the youngest Kula volcanics (Western Anatolia), with a new emplacement model. Turkish Journal of Earth Sciences, 14, 145-166.

Tyrrell, G.W., 1932. The basalts of Patagonia, The Journal of Geology, 40, 374-383.

Walker, G.P.L., 1999. Volcanic rift zones and their intrusion swarms. Journal of Volcanology and Geothermal Research, 94, 21-34.

Washington, H.S., 1900. The composition of Kulaite. The Journal of Geology, 8, 610620. 
Westaway, R., Pringle, M., Yurtmen, S., Demir, T., Bridgland, D., Rowbotham, G., and Maddy, D., 2004. Pliocene and Quaternary regional uplift in western Turkey: the Gediz river terrace staircase and the volcanism at Kula. Tectonophysics, 391, 121-169.

Westaway, R., Guiillou, H., Yurtmen, S., Demir, T., Scaillet, S., and Rowbotham, G., 2005. Constraints on the timing and regional conditions at the start of the presence phase of crustal extension in western Turkey, from observations in and around the Denizli region. Geodinamica Acta, 18, 209-238.

Westaway, R., Guillou, H., Yurtmen, S., Beck, A., Bridgland, D., Demir, T., Scaillet, S., and Rowbotham, G., 2006. Late Cenozoic uplift of western Turkey: Improved dating of the Kula Quaternary volcanic field and numerical modelling of the Gediz river terrace staircase, Global and Planetary Change, 51, 131-171.

White, R.S., and McKenzie, D.P., 1989. Magmatism at rift zones: The generation of volcanic continental margins and flood basalts. Journal of Geophysical Research, 94, 7685-7729

Wohletz, K.H., and McQueen, R.G., 1984. Experimental Studies of Hydromagmatic Volcanism. Studies of Geophysics. National Academic Press, Washington, 158-169
Wood, C. A., 1974. Reconnaissance geophysics an geology of the Pinacate Craters, Sonora, Mexico. Bulletin of Volcanology, 38, 149-172.

Wood, C. A., 1980. Morphometric evolution of cinder cones. Journal of Volcanology and Geothermal Research, 7, 387-413.

Yılmaz, Y., 1989. An approach to the origin of young volcanic rocks of western Turkey. In: Șengör, A.M.C. (Ed.), Tectonic Evolution of the Tethyan Region. Kluwer Academic Publishers, 159-189.

Yilmaz, Y., 1990. Comparison of young volcanic associations of western and eastern Anatolia formed under a compressional regime: a review. Journal of Volcanology and Geothermal Research, 44, 1-19.

Yılmaz, Y., Genç, Ș.C., Gürer, F., Bozcu, M., Yılmaz, K., Karacık, Z., Altunkaynak, Ș., and Elmas, A., 2000. When did the Western Anatolian grabens begin to develop? Bozkurt, E. Winchester, J.A., Piper J.A.D. (Eds.), Tectonics and Magmatism in Turkey and the Surrounding Area. Journal of Geological Society of London, 173, 131-162. 
